Marquette University

e-Publications@Marquette

Biological Sciences Faculty Research and

Publications

Biological Sciences, Department of

$7-2020$

\title{
Potent Inhibition of Mandelate Racemase by Boronic Acids: Boron as a Mimic of a Carbon Acid Center
}

Amar Nath Sharma

Dalhousie University

Lia Grandinetti

Marquette University

Erin R. Johnson

Dalhousie University

Martin St. Maurice

Marquette University, martin.stmaurice@marquette.edu

Stephen L. Bearne

Dalhousie University

Follow this and additional works at: https://epublications.marquette.edu/bio_fac

Part of the Biology Commons

\section{Recommended Citation}

Sharma, Amar Nath; Grandinetti, Lia; Johnson, Erin R.; St. Maurice, Martin; and Bearne, Stephen L., "Potent Inhibition of Mandelate Racemase by Boronic Acids: Boron as a Mimic of a Carbon Acid Center" (2020). Biological Sciences Faculty Research and Publications. 824.

https://epublications.marquette.edu/bio_fac/824 
Marquette University

e-Publications@Marquette

\title{
Biological Sciences Faculty Research and Publications/College of Arts and Sciences
}

This paper is NOT THE PUBLISHED VERSION.

Access the published version via the link in the citation below.

Biochemistry, Vol. 59, No. 33 (July 2020): 3026-3037. DOI. This article is (C) American Chemical Society Publications and permission has been granted for this version to appear in e-Publications@Marquette. American Chemical Society Publications does not grant permission for this article to be further copied/distributed or hosted elsewhere without the express permission from American Chemical Society Publications.

\section{Potent Inhibition of Mandelate Racemase by Boronic Acids: Boron as a Mimic of a Carbon Acid Center}

\author{
Amar Nath Sharma \\ Department of Biochemistry and Molecular Biology, Dalhousie University, Halifax, NS B3H 4R2, Canada \\ Lia Grandinetti \\ Department of Biological Sciences, Marquette University, Milwaukee, Wisconsin \\ Erin R. Johnson \\ Department of Chemistry, Dalhousie University, Halifax, NS B3H 4R2, Canada \\ Martin St. Maurice \\ Department of Biological Sciences, Marquette University, Milwaukee, Wisconsin \\ Stephen L. Bearne \\ Department of Biochemistry and Molecular Biology, Dalhousie University, Halifax, NS B3H 4R2, Canada \\ Department of Chemistry, Dalhousie University, Halifax, NS B3H 4R2, Canada
}




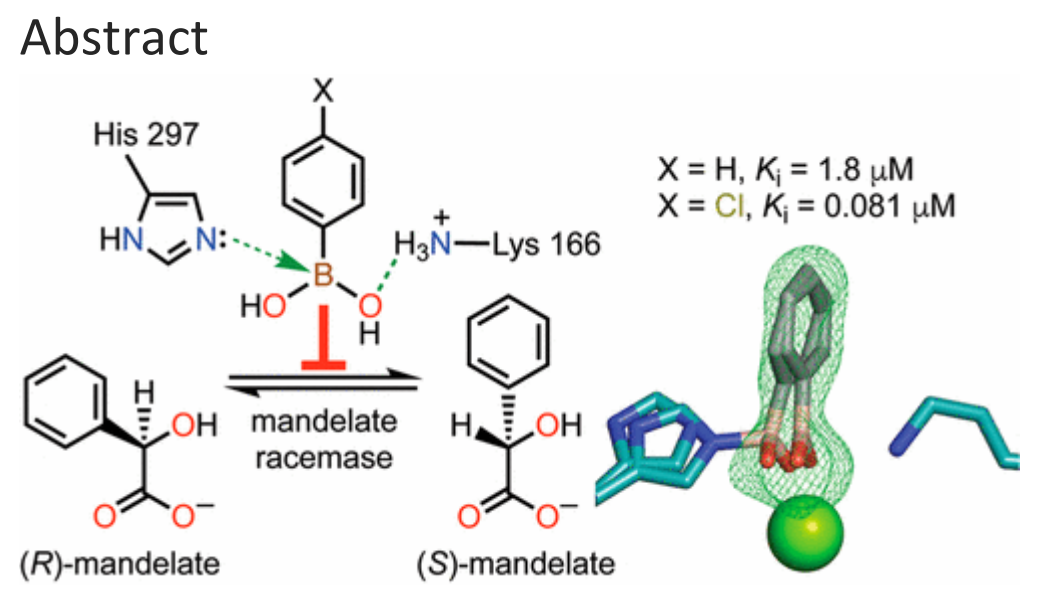

Boronic acids have been successfully employed as inhibitors of hydrolytic enzymes. Typically, an enzymatic nucleophile catalyzing hydrolysis adds to the electrophilic boron atom forming a tetrahedral species that mimics the intermediate(s)/transition state(s) for the hydrolysis reaction. We show that para-substituted phenylboronic acids (PBAs) are potent competitive inhibitors of mandelate racemase (MR), an enzyme that catalyzes a 1,1proton transfer rather than a hydrolysis reaction. The $K_{\mathrm{i}}$ value for PBA was $1.8 \pm 0.1 \mu \mathrm{M}$, and $p$-Cl-PBA exhibited the most potent inhibition ( $K_{\mathrm{i}}=81 \pm 4 \mathrm{nM}$ ), exceeding the binding affinity of the substrate by $\sim 4$ orders of magnitude. Isothermal titration calorimetric studies with the wild-type, K166M, and H297N MR variants indicated that, of the two Brønsted acid-base catalysts Lys 166 and His 297, the former made the greater contribution to inhibitor binding. The X-ray crystal structure of the MR.PBA complex revealed the presence of multiple $\mathrm{H}$-bonds between the boronic acid hydroxyl groups and the side chains of active site residues, as well as formation of a His $297 \mathrm{~N}^{\varepsilon 2}-\mathrm{B}$ dative bond. The dramatic upfield change in chemical shift of $27.2 \mathrm{ppm}$ in the solution-phase ${ }^{11} \mathrm{~B}$ nuclear magnetic resonance spectrum accompanying binding of PBA by MR was consistent with an $\mathrm{sp}^{3}$-hybridized boron, which was also supported by density-functional theory calculations. These unprecedented findings suggest that, beyond substituting boron at carbon centers participating in hydrolysis reactions, substitution of boron at the acidic carbon center of a substrate furnishes a new approach for generating inhibitors of enzymes catalyzing the deprotonation of carbon acid substrates.

Over the past decade, interest in employing boron in the design of enzyme inhibitors and potential therapeutic agents has grown.(1-9) This interest arises because boron-containing biomolecules exhibit low toxicity(6) and are not abundant in nature, although natural boron-containing antibiotics and cell surface signaling molecules do exist.(10) Moreover, the boron atom acts as a Lewis acid(11) with its vacant $p$ orbital readily accepting electrons from donor atoms to form a coordinate covalent (dative) bond with concomitant conversion from a neutral $\mathrm{sp}^{2}$ center to an anionic $\mathrm{sp}^{3}$ center. The electron donors are typically the side chains of Ser, $(12-15)$ Thr, (16) His, $(17,18)$ or Lys, (19) which can interact directly with the boron atom or via an intervening water molecule(20) (Scheme 1). Furthermore, the boron atom is often covalently linked to one or two hydroxyl groups; hence, it can act as an acceptor or donor of $\mathrm{H}$-bonds for additional molecular recognition.(21) Consequently, enzymes often bind boron-based inhibitors with high affinity such that the inhibition is effectively irreversible.(6) Traditionally, the boronic acid group has been employed for the design of inhibitors of hydrolytic enzymes, where either water(22) or the hydroxyl group of a Ser or Thr residue of the enzyme $(5,6,9,23)$ reacts with the trigonal planar boronic acid group to yield a tetrahedral adduct that mimics the geometric and electronic features of the tetrahedral intermediate(s) and/or transition states (TSs) formed during hydrolysis (Scheme 1). We hypothesized that the Lewis acidity of the boronic acid functional group might also permit strong interactions with the Brønsted base catalyst(s) present at the active sites of enzymes that 
catalyze heterolytic cleavage of a $\mathrm{C}-\mathrm{H}$ bond. Indeed, many different enzymes catalyze such proton abstraction reactions, often to initiate 1,1-, 1,2-, or 1,3-migrations of protons, aldol or Claisen condensations, or $\beta$ elimination reactions.(24-26) Racemases and epimerases that utilize a two-base mechanism(27) offer particularly attractive targets because the Brønsted acid-base catalysts are located on opposite sides of the carbon atom where deprotonation occurs. This active site architecture should afford the potential for interactions between the enzyme and the boron atom of an inhibitor.

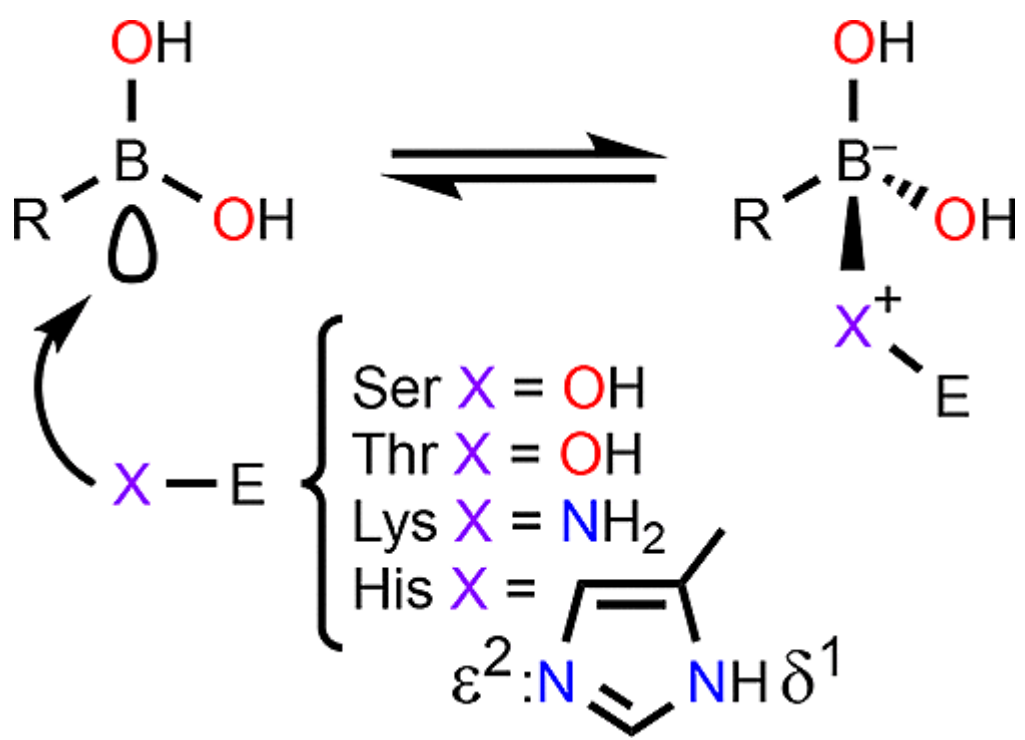

Scheme 1. Typical Adducts Formed between the Side Chains of Protein Amino Acid Residues and Boronic Acid Ligands

As a model system, we explored the inhibition of mandelate racemase (MR) by various boronic acids. MR has served as a powerful paradigm for developing our understanding of how enzymes overcome the thermodynamic and kinetic barriers accompanying the abstraction of a proton from a carbon acid substrate, as well as our general understanding of enzyme catalysis. $(24,28-31)$ The enzyme utilizes a two-base mechanism with either Lys 166 or His 297 acting as the enantiospecific Brønsted base to abstract the $\alpha$-proton from $(S)$ - or $(R)$ mandelate, respectively (Scheme 2).(32-34) The resulting aci-carboxylate intermediate is subsequently reprotonated by the conjugate acid of the Brønsted base, located antipodal to the Brønsted base that effected deprotonation, to afford the enantiomeric product. Considering the arrangement of the Lys and His side chains around the stereogenic $\alpha$-carbon, we envisioned that potent inhibition might arise if a bound boron-bearing inhibitor positioned the boron atom at the location normally occupied by the $\alpha$-carbon of the substrate, thereby allowing for formation of N-B interactions.(35-42) Herein, we report that derivatives of phenylboronic acid (PBA) are the most potent inhibitors of MR yet described, exceeding the binding affinity of TS analogue inhibitors by $\sim 1-2$ orders of magnitude. $(43,44) X$-ray crystallographic studies reveal that the boronic acid moiety of the inhibitor is "gripped" by key catalytic residues at the active site, capitalizing on the ability of the boronic acid group to form multiple $\mathrm{H}$-bonds. Moreover, crystallographic and ${ }^{11} \mathrm{~B}$ nuclear magnetic resonance (NMR) evidence supports the formation of an N-B dative bond between PBA and the Brønsted acid-base catalyst His 297. Our results suggest that replacement of the acidic carbon of a carbon acid substrate with an electrophilic boron atom expands the scope of boronic acids beyond their use as carboxylate isosteres and as inhibitors targeting hydrolytic enzymes. 


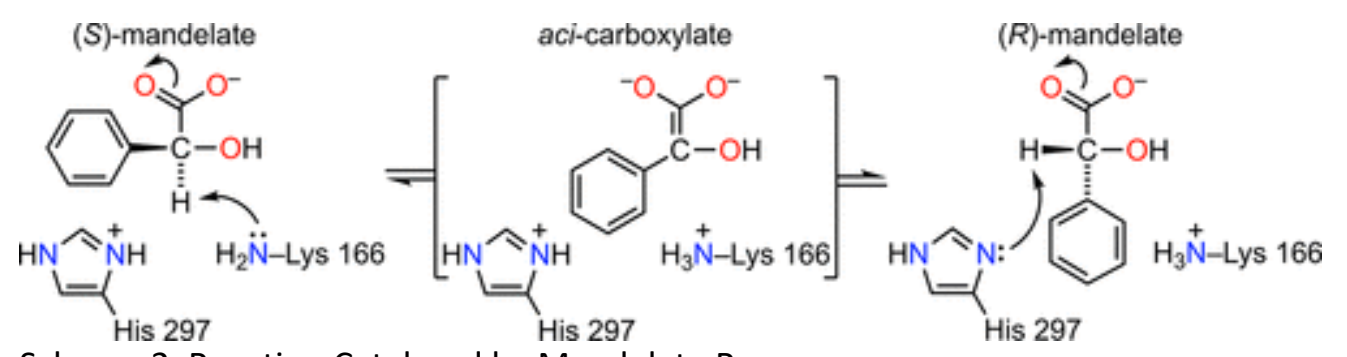

Scheme 2. Reaction Catalyzed by Mandelate Racemase

\section{Materials and Methods}

\section{General}

All reagents, unless mentioned otherwise, were purchased from Sigma-Aldrich Canada Ltd. (Oakville, ON). 4Methylphenylboronic acid and methylboronic acid were purchased from TCl America (Portland, OR). The $(R)$ and (S)-enantiomers of 4-chloromandelic acid were purchased from DSM Pharma Chemicals Regensburg GmbH (Regensburg, Germany). Circular dichroism (CD) spectral measurements were conducted using a JASCO J-810 spectropolarimeter (Jasco Inc., Easton, MI). Binding studies were conducted using a VP-ITC microcalorimeter (MicroCal, Inc., Northampton, MA). ${ }^{11}$ B NMR spectra were recorded using a Brüker AVANCE 500 NMR spectrometer at the Dalhousie Nuclear Magnetic Resonance Research Resource (NMR-3) Centre.

\section{Enzyme Purification}

Strepll-tagged recombinant variants of MR (wild-type MR, K166M-MR, and H297N-MR)(45) were overexpressed in and purified from Escherichia coli BL21(DE3) cells transformed with the appropriate plasmid as described previously.(46) These constructs encode the wild-type or mutant MR gene products as fusion proteins with an $\mathrm{N}$-terminal Strepll tag (MASWSHPQFEKGALEVLFQGPGYHM ${ }_{1}-\mathrm{MR}$, where $\mathrm{M}_{1}$ denotes the initial Met of either the wild-type or variant MRs and the Strepll tag is underlined). The purity of the wild-type and variant MRs ( $\geq 99 \%)$ was assessed using sodium dodecyl sulfate-polyacrylamide gel electrophoresis (12\% acrylamide) with staining by Coomassie blue R-250.(47) Protein concentrations were determined from the intrinsic enzyme absorbance at $280 \mathrm{~nm}$ using an extinction coefficient $\varepsilon$ of $53400 \mathrm{M}^{-1} \mathrm{~cm}^{-1}$ for all MR variants estimated using the ProtParam program from ExPasy (http://web.expasy.org/protparam/).(48) The Strepll tag was not removed from the enzymes.

\section{Inhibition Studies}

MR activity was assayed using a CD-based assay by following the change in ellipticity of mandelate at $262 \mathrm{~nm}$ with a $1 \mathrm{~cm}$ light path (unless otherwise indicated) as described by Sharp et al.(49) All inhibition experiments were conducted at $25^{\circ} \mathrm{C}$ in Na+-HEPES buffer $\left(0.1 \mathrm{M}\right.$, pH 7.5) containing $\mathrm{MgCl}_{2}(3.3 \mathrm{mM})$ and bovine serum albumin (BSA, 0.005\%). Wild-type $\mathrm{MR}(150 \mathrm{ng} / \mathrm{mL})$ was assayed with $(R)$-mandelate $(0.5-15.0 \mathrm{mM})$ as the substrate and varying concentrations of PBA $(1.00,2.00$, and 5.00 $\mu \mathrm{M}), 4-\mathrm{Br}-\mathrm{PBA}(0.08,0.16$, and $0.24 \mu \mathrm{M}), 4-\mathrm{Cl}-$ PBA $(0.08,0.16$, and $0.24 \mu \mathrm{M}), 4-\mathrm{CH}_{3}-\mathrm{PBA}(0.50,1.00$, and $1.50 \mu \mathrm{M}), 4-\mathrm{CF}_{3}-\mathrm{PBA}(0.25,0.50$, and $0.75 \mu \mathrm{M})$, 4-CNPBA $(2.50,5.00$, and $7.50 \mu \mathrm{M}), 4-F-P B A(0.20,0.40$, and $0.60 \mu \mathrm{M}), 4-\mathrm{NO}_{2}-\mathrm{PBA}(0.50,1.00$, and $1.50 \mu \mathrm{M}), 4-\mathrm{OCH}_{3}$ PBA $(4.00,8.00$, and $12.00 \mu \mathrm{M})$, cyclohexylboronic acid $(1.50,3.00$, and $4.20 \mathrm{mM})$, and methylboronic acid $(0.125,0.250$, and $0.375 \mathrm{M})$. The apparent kinetic constants $V_{\max }$ and $K_{\mathrm{m}}$ were determined by fitting eq 1 to the initial velocity data using nonlinear regression analysis and KaleidaGraph ver. 4.02 from Synergy Software (Reading, PA). All kinetic parameters were determined in triplicate, and average values are reported. The reported errors are the standard deviations. 


$$
v_{i}=\frac{V_{\max }[S]}{K_{\mathrm{m}}+[S]}
$$

(1)

Competitive inhibition constants $\left(K_{i}\right)$ for the inhibition of MR by the 4-substituted PBAs were determined from plots of the apparent $K_{\mathrm{m}} / V_{\max }$ values versus inhibitor concentration in accord with eq 2.(50)

$$
v_{i}=\frac{V_{\max }[S]}{K_{\mathrm{m}}\left(1+\frac{[I]}{K_{\mathrm{i}}}\right)+[S]}
$$

(2)

The $\mathrm{IC}_{50}$ values for the inhibition of wild-type MR by 4-Cl-PBA (40-640 nM) at MR concentrations of 150, 300, and $450 \mathrm{ng} / \mathrm{mL}$ were determined, relative to $(R)$-mandelate $(1.0 \mathrm{mM})$, by fitting eq 3 to the relative velocities $\left(v_{i} / v_{0}\right)$ obtained at the indicated concentrations. The $I_{50}$ value is the concentration of the inhibitor that yields a $v_{i} / v_{0}$ of 0.5 , and $n$ is the Hill number.(50)

$$
\frac{v_{i}}{v_{0}}=\frac{\mathrm{IC}_{50}^{N}}{\mathrm{IC}_{50}^{N}+[\mathrm{I}]^{N}}
$$

(3)

\section{Reversibility and Effect of Enzyme Concentration}

The reversibility of inhibition by PBA were evaluated by measuring the recovery of enzyme activity after dialysis. Wild-type MR (1500 ng/mL) was incubated with PBA $(0 \mu \mathrm{M}$, as a control, and $30 \mu \mathrm{M}$ each in $3.0 \mathrm{~mL})$ at $25^{\circ} \mathrm{C}$ for $20 \mathrm{~min}$, yielding $10 \%$ of the enzymatic activity. After dialysis against assay buffer ( $3 \times 250 \mathrm{~mL}$ over $24 \mathrm{~h}$ ), both the control and PBA-containing samples were assayed for enzymatic activity.

\section{Assay with 4-Chloromandelate}

The ability of MR to catalyze the racemization of $(R)$ - and $(S)$-4-chloromandelate was examined using a CD-based assay. The CD spectra of $(R)$ - and $(S)$-4-chloromandelate $(10 \mathrm{mM})$ in assay buffer were recorded, and a suitable wavelength at which 4-chloromandelate exhibited a pronounced signal was chosen $(276 \mathrm{~nm})$. The molar

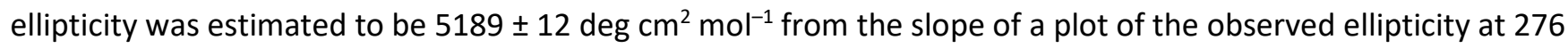
$\mathrm{nm}$ against five concentrations of $(R)$-4-chloromandelate $(2.0,4.0,6.0,8.0$, and $10.0 \mathrm{mM})$. The values of $k_{\text {cat }}\left(V_{\mathrm{max}} /[\mathrm{E}]_{\mathrm{T}}\right)$ and $K_{\mathrm{m}}$ were then determined in accord with eq 1 by measuring the initial rates for the racemization of $(R)$ - and $(S)$-4-chloromandelate $(0-10 \mathrm{mM})$ catalyzed by wild-type $\mathrm{MR}(150 \mathrm{ng} / \mathrm{mL})$.

\section{Isothermal Titration Calorimetry}

Ligand solutions containing PBA were prepared in the final dialysis buffer to eliminate heat signals that could arise from buffer mismatch. MR variants and ligand solutions were degassed (Microcal Thermovac) for $15 \mathrm{~min}$ prior to being loaded into the sample cell $(1.46 \mathrm{~mL})$ and the injection syringe $(297 \mu \mathrm{L})$, respectively. The stirred cell contained either wild-type MR $(45 \mu \mathrm{M}), \mathrm{H} 297 \mathrm{~N}-\mathrm{MR}(50 \mu \mathrm{M})$, or K166M-MR $(60 \mu \mathrm{M})$, and the injection syringe contained various concentrations of PBA ( $1.0 \mathrm{mM}, 6.0 \mu \mathrm{L} /$ injection with wild-type $\mathrm{MR} ; 2.0 \mathrm{mM}, 6.0$ $\mu \mathrm{L} /$ injection with $\mathrm{H} 297 \mathrm{~N}-\mathrm{MR}$; and $26.22 \mathrm{mM}, 6.0 \mu \mathrm{L}$ /injection with $\mathrm{K} 166 \mathrm{M}-\mathrm{MR}$ ). Titrations were conducted at 20 ${ }^{\circ} \mathrm{C}$. The heat released due to the initial injection (typically $2-5 \mu \mathrm{L}$ ) was excluded from data analyses to minimize the effect of diffusion of the titrant from the syringe tip during the equilibration process. To correct for the heats of dilution and mixing, ligand titrations were also conducted with the sample cell containing only buffer. The 
dilution isotherm for each ligand was subtracted from the appropriate binding isotherm prior to curve fitting. Binding affinities and the $\Delta H$ and $\Delta S$ values for binding of PBA to the MR variants were obtained by fitting the calorimetric data with a single-site model using the Origin 7.0 software (OriginLab, Northampton, MA). For K166M-MR, the binding of PBA was weak and the experiment was limited by our inability to utilize higher concentrations of PBA due to precipitation of the protein. Curve fitting was therefore conducted by fixing the molar ratio $(n)$ at 1.

\section{${ }^{11}$ B NMR Spectroscopy}

All NMR spectra were recorded at $25^{\circ} \mathrm{C}$ in $\mathrm{Na}^{+}$-HEPES buffer $(0.1 \mathrm{M}, \mathrm{pH} 7.5)$ containing $\mathrm{MgCl}_{2}(3.3 \mathrm{mM})$ and $\mathrm{D}_{2} \mathrm{O}$ $(10 \%)$. Chemical shifts $(\delta)$ of the signals arising from ${ }^{11} \mathrm{~B}$ are reported relative to an external standard of $\mathrm{BF}_{3} \cdot \mathrm{OEt}_{2}(\delta=0.00 \mathrm{ppm}$ ). Samples were in $5 \mathrm{~mm}$ quartz tubes (Sigma-Aldrich Canada $\mathrm{Ltd}$.) to reduce the background signal arising from the boron in borosilicate glass. For the spectra of PBA in the presence of MR, the concentration of PBA was fixed at either 300 or $400 \mu \mathrm{M}$, and the spectra were recorded with varying amounts of wild-type MR added to the solution $(0-300 \mu \mathrm{M})$. The background signal arising from borosilicate glass in the spectrometer probe was reduced in the spectra using Whittaker smoothing.(51)

\section{Protein Crystallization}

Crystals of wild-type MR were grown in the presence of PBA by the sitting-drop vapor diffusion method against a reservoir volume of $500 \mu \mathrm{L}$. The protein solution and reservoir solution were mixed in a 1:1 ratio to give a final volume of $10 \mu \mathrm{L}$. Crystals grew spontaneously at $21^{\circ} \mathrm{C}$. The reservoir solution consisted of PEG 4000 [10\% (w/v)] and Bis-Tris Propane (BTP; $50 \mathrm{mM}, \mathrm{pH} 7.0)$. The protein solution consisted of $\mathrm{MR}(6 \mathrm{mg} / \mathrm{mL})$ purified as described above, PBA (1.0 mM), $\mathrm{MgCl}_{2}(3.3 \mathrm{mM})$, and $\mathrm{Na}^{+}$-HEPES buffer (50 mM, pH 7.5). The resulting cubelike crystals $(\sim 50 \mu \mathrm{m} \times 40 \mu \mathrm{m} \times 40 \mu \mathrm{m})$ grew to full size within 15-20 days. Crystals were harvested and transferred to a synthetic stabilizing solution consisting of PEG 4000 [8\% (w/v)], BTP (80 mM, pH 7.0), ethylene glycol [5\% $(\mathrm{w} / \mathrm{v})]$, PBA $(0.77 \mathrm{mM}), \mathrm{MgCl}_{2}(1.65 \mathrm{mM})$, and $\mathrm{Na}^{+}$-HEPES buffer $(25 \mathrm{mM}, \mathrm{pH} 7.5)$. These stabilized crystals were equilibrated in the synthetic stabilizing solution for $5 \mathrm{~min}$ and then transferred directly to a cryoprotectant solution consisting of PEG 4000 [10\% (w/v)], BTP (80 mM), ethylene glycol [20\% (w/v)], PBA (0.8 mM), $\mathrm{MgCl}_{2}(1.58 \mathrm{mM})$, and $\mathrm{Na}^{+}$-HEPES buffer $(24 \mathrm{mM}, \mathrm{pH} 7.5)$. The cryoprotected crystals were flash-frozen in a stream of nitrogen gas at $100 \mathrm{~K}$.

\section{Data Collection, Structure Determination, and Refinement}

X-ray diffraction data were collected at the Life Sciences Collaborative Access Team beamline 21-ID-G at the Advanced Photon Source, Argonne National Laboratory, on a Rayonix MarMosaic 300 CCD detector with an Xray wavelength of $0.979 \AA$. Diffraction images were autoprocessed using the autoPROC software workflow,(52) which merged and scaled the isotropic data in AIMLESS(53) with the programs TRUNCATE(54) and UNIQUE(55) to automatically determine the resolution limit. The phases were determined by the molecular replacement method, using the wild-type MR enzyme with bound BzH [Protein Data Bank (PDB) entry 3UXK] as the search model,(56) with the program Phaser.(57) The molecular replacement models were extended by several rounds of manual model building with COOT(58) and refinement with Phenix.Refine(59) with an Xray/stereochemistry weight of 2.0 applied in the final rounds of refinement. Noncrystallographic restraints between each monomer were applied for the first round of refinement but were relieved for subsequent rounds. Water molecules were added to the model in COOT and Phenix. Refine with subsequent manual verification. The final refined ligand coordinates for PBA were optimized for structure refinement using eLBOW (electronic ligand building and optimization workbench).(60) For each dimer, one active site (chains A, C, E, and G) was modeled with single occupancy by PBA with a $C-B-O^{\alpha}-O^{\beta}$ dihedral angle of $\sim 145^{\circ}$ (intermediate between $\mathrm{sp}^{2}$ - and $\mathrm{sp}^{3}$-hydridized), while the other active site in the adjacent subunit (chains $B, D, F$, and $H$ ) was modeled at $50 \%$ occupancy by PBA with a $\mathrm{C}-\mathrm{B}-\mathrm{O}^{\alpha}-\mathrm{O}^{\beta}$ dihedral angle of $\sim 165^{\circ}$ ( $\sim \mathrm{sp}^{2}$-hydridized) and at $50 \%$ 
occupancy by PBA with a $\mathrm{C}-\mathrm{B}-\mathrm{O}^{\alpha}-\mathrm{O}^{\beta}$ dihedral angle of $\sim 120^{\circ}$ ( $\sim \mathrm{sp}^{3}$-hydridized). The side chain of His 297 was also modeled in two conformations for chains $B, D, F$, and $H$. The model was refined using a ligand definition file for $\mathrm{PBA}$ with a $\mathrm{C}-\mathrm{B}-\mathrm{O}^{\alpha}-\mathrm{O}^{\beta}$ dihedral angle of $145^{\circ}$, with loose restraints. For chains $\mathrm{B}, \mathrm{D}$, and $\mathrm{F}$, the refinement supported two distinct conformations for PBA and His 297, each at 50\% occupancy. However, for chain $\mathrm{H}$, the refinement resulted in both conformations converging to a single conformation for His 297 and a single conformation for $\mathrm{PBA}$, with a $\mathrm{C}-\mathrm{B}-\mathrm{O}^{\alpha}-\mathrm{O}^{\beta}$ dihedral angle of $166^{\circ}$. Consequently, subsequent refinements modeled only a single conformation for PBA and His 297 in chain $\mathrm{H}$. Data collection and processing statistics are summarized in Table S1.

\section{Density-Functional Theory (DFT) Calculations}

All calculations were performed using the Gaussian 09(61) and postg(62) programs, with the LC- $\omega$ PBE density functional.(63) The exchange-hole dipole moment (XDM) method $(62,64)$ was used to include dispersion interactions in all geometry optimizations, with the following damping-function parameters: $a_{1}=0.6889$ and $a_{2}=$ $1.9452 \AA$. The geometry optimizations used a mixed basis set, with the 6-31G* basis assigned to boron, carbon, and hydrogen, and the larger $6-31+G^{*}$ basis assigned to nitrogen and oxygen. The initial geometry was obtained from the coordinates of chain $F$ from the $X$-ray crystal structure of MR with bound PBA (PDB entry 6VIM) refined with a single PBA at $100 \%$ occupancy (i.e., $\mathrm{C}-\mathrm{B}-\mathrm{O}^{\alpha}-\mathrm{O}^{\beta}$ dihedral angle of $167.9^{\circ}$; His $297 \mathrm{~N}^{\varepsilon 2}-\mathrm{B}$ and Lys $166 \mathrm{~N}^{2}-\mathrm{B}$ distances of 2.50 and $2.99 \AA$, respectively) and a single conformation of His 297 , utilizing the first shell of residues interacting with PBA (Asn 197, Lys 164, Lys 166, and $\mathrm{His} 297$ ), the $\mathrm{Mg}^{2+}$ ion and its ligands $\left(\mathrm{H}_{2} \mathrm{O}, \mathrm{Asp}\right.$ 195, Glu 221, and Glu 247), and Asp 270, which forms a catalytic dyad with His 297.(65) The amino acids were truncated (by hydrogen capping) at the $\mathrm{sp}^{3}$ or $\alpha$-carbon atoms, the positions of which were held fixed during geometry optimizations, while all other atomic positions were allowed to relax. Several combinations of $\mathrm{H}$ atom positions and protonation states were considered, and the most stable retained. The ${ }^{11} \mathrm{~B} N \mathrm{NR}$ chemical shifts were calculated with the Gauge-Independent Atomic Orbital (GIAO) method,(66) using the 6-31+G* basis set for all atoms. Analogous calculations were also carried out for an isolated PBA molecule. The boron chemical shifts are expressed relative to that for free PBA in assay buffer (i.e., $\delta=28.2 \mathrm{ppm}$ ).

\section{Results and Discussion}

\section{Inhibition of MR by PBAs}

In accord with our hypothesis, PBA was a potent competitive inhibitor of MR with a $K_{\mathrm{i}}$ value of $1.8 \mu \mathrm{M}$ (Table 1 ), binding with an affinity $\sim 556$-fold greater than that observed for the substrate $\left(K_{\mathrm{m}}=K_{\mathrm{S}} \approx 1 \mathrm{mM}\right)$.(67) The onset of inhibition was rapid, and dialysis of the enzyme-inhibitor solution resulted in full recovery of enzyme activity, indicating that the inhibition was reversible. To investigate the dependence of the binding affinity on the identity of substituents on the phenyl ring, we determined the $K_{\mathrm{i}}$ values for a series of 4 -substituted PBAs (Table 1 and Figures S1-S9). Plotting the observed $\log \left(K_{\mathrm{i}}^{\mathrm{X}} / K_{\mathrm{i}}^{\mathrm{H}}\right)$ values against the Hammett substituent constants ( $\left.\sigma_{\text {para }}\right)$ gave a concave-up pattern (Figure 1).(68) The decreased binding affinity of PBA derivatives with bulky electron-withdrawing substituents at the para position of the phenyl ring likely arose from unfavorable steric and polar interactions as observed previously for the weak binding of 4-nitromandelate,(67) rather than electronic effects. However, for the free energies accompanying binding of PBA derivatives bearing smaller para substituents $\left(\mathrm{H}, \mathrm{CH}_{3}, \mathrm{~F}, \mathrm{Br}, \mathrm{Cl}\right.$, and, surprisingly, $\left.\mathrm{OCH}_{3}\right)$, there was a roughly linear correlation $(\rho=$ $-2.9 \pm 0.8)$ indicating that electron-withdrawing character favored binding. A similar observation was reported for the inhibition of subtilisin by a limited number of phenylboronic acids (i.e., $\rho=-0.895$ ).(69) [Note that, as shown in Figure S10, using the $\mathrm{p} K_{\mathrm{a}}$ values (Table S2) to adjust the $K_{\mathrm{i}}$ values assuming either the neutral trigonal or anionic tetrahedral boronic acid was the inhibitor did not significantly alter the shape of the plot, nor did plotting the data as a function of $\sigma_{\text {para. }}^{-}$.] The most potent inhibitor was 4-Cl-PBA, binding with a $K_{\mathrm{i}}$ value approximately $1.23 \times 10^{4}$-fold lower than that of the substrate. 
Table 1. Inhibition of MR by Boronic Acids

\begin{tabular}{|c|c|c|}
\hline compound & $K_{\mathrm{i}}(\mu \mathrm{M})^{\mathrm{a}}$ & inhibition mode $^{b}$ \\
\hline PBA & $1.8 \pm 0.1$ & $C$ \\
\hline 4-Br-PBA & $0.123 \pm 0.007$ & C \\
\hline \multirow[t]{2}{*}{ 4-Cl-PBA } & $0.081 \pm 0.004$ & $\mathrm{C}$ \\
\hline & $\begin{array}{l}I C_{50}=0.149 \pm 0.006 \mu \mathrm{M}([\mathrm{MR}]=150 \mathrm{ng} / \mathrm{mL}) ; \mathrm{I} C_{50}= \\
0.14 \pm 0.01 \mu \mathrm{M}([\mathrm{MR}]=300 \mathrm{ng} / \mathrm{mL}) ; \mathrm{IC} C_{50}=0.142 \pm 0.003 \mu \mathrm{M} \\
([\mathrm{MR}]=450 \mathrm{ng} / \mathrm{mL})\end{array}$ & \\
\hline $4-\mathrm{CH}_{3}-\mathrm{PBA}$ & $0.67 \pm 0.07$ & $\mathrm{C}$ \\
\hline $4-\mathrm{CF}_{3}-\mathrm{PBA}$ & $0.21 \pm 0.01$ & $\mathrm{C}$ \\
\hline 4-CN-PBA & $2.93 \pm 0.02$ & C \\
\hline 4-F-PBA & $0.23 \pm 0.01$ & $\mathrm{C}$ \\
\hline $4-\mathrm{NO}_{2}-\mathrm{PBA}$ & $0.66 \pm 0.05$ & $\mathrm{C}$ \\
\hline 4- $\mathrm{OCH}_{3}-\mathrm{PBA}$ & $4.1 \pm 0.2$ & C \\
\hline cyclohexylboronic acid & $(1.56 \pm 0.05) \times 10^{3}$ & $\mathrm{C}$ \\
\hline methylboronic acid & $K_{\mathrm{i}}=(1.3 \pm 0.1) \times 10^{5} ; \alpha K_{\mathrm{i}}=(7.1 \pm 0.1) \times 10^{5}$ & LM \\
\hline
\end{tabular}

${ }^{\mathrm{a}} K_{\mathrm{m}}=K_{\mathrm{s}} \approx 1000 \mu \mathrm{M}$.(67)

${ }^{\mathrm{b} C o m p e t i t i v e ~(C) ~ a n d ~ l i n e a r ~ m i x e d-t y p e ~(L M) ~ i n h i b i t i o n . ~}$

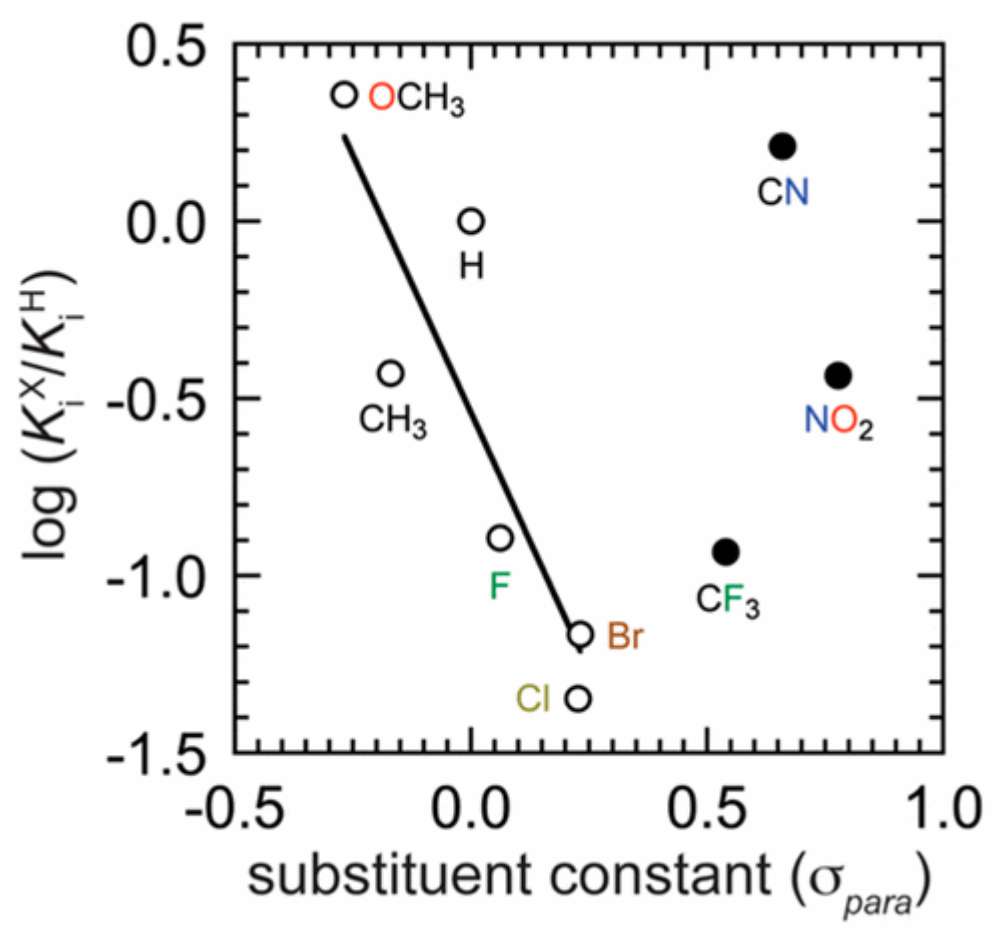

Figure 1. Hammett plot for the inhibition of MR by para-substituted phenylboronic acids. The $\log \left(K_{\mathrm{i}}^{\mathrm{X}} / K_{\mathrm{i}}{ }^{\mathrm{H}}\right)$ values, where $K_{\mathrm{i}}^{\mathrm{X}}$ is the observed $K_{\mathrm{i}}$ value for a given para-substituted PBA, are plotted against the para-substituent constant $\left(\sigma_{\text {para }}\right)$. The line shown is the linear regression line [slope $(\rho)=-2.9 \pm 0.8$ ] for the PBA derivatives for which $\mathrm{X}=\mathrm{H}, \mathrm{Br}, \mathrm{Cl}, \mathrm{CH}_{3}, \mathrm{~F}$, and $\mathrm{OCH}_{3}(\mathrm{O})$. The bulkier electron-withdrawing groups (i.e., $\mathrm{X}=\mathrm{NO}_{2}$, $\mathrm{CN}$, and $\mathrm{CF}_{3}$ ) likely deviate from the correlation due to unfavorable steric and polar effects on binding $(\bullet) .(67)$

To assess whether this enhanced binding arose from electronic effects or some fortuitous interaction(s) with the chloro substituent, we determined the molar ellipticity of $(R)$ - and (S)-4-chloromandelate (Figure S11) and investigated the kinetic parameters for MR acting on 4-chloromandelate as an alternative substrate (Figure S12). (70) Although the turnover numbers $\left(k_{\text {cat }}\right)$ for $(R)$-4-chloromandelate $\left(1343 \pm 43 \mathrm{~s}^{-1}\right)$ and $(S)$-4chloromandelate $\left(1329 \pm 33 \mathrm{~s}^{-1}\right)$ were greater than the corresponding values for $(R)$-mandelate $\left(1029 \mathrm{~s}^{-1}\right)$ and 
(S)-mandelate $\left(775 \mathrm{~s}^{-1}\right),(71)$ the $K_{\mathrm{m}}$ values of $(R)$-4-chloromandelate $(1.09 \pm 0.06 \mathrm{mM})$ and $(S)$-4-chloromandelate $(0.90 \pm 0.07 \mathrm{mM})$ were similar to those of $(R)$-mandelate $(1.03 \pm 0.05 \mathrm{mM})$ and $(S)$-mandelate $(0.76 \pm 0.03 \mathrm{mM})$, respectively.(71) Hence, the enhanced binding of 4-Cl-PBA likely arose from the electron-withdrawing effect of the chloro substituent. Because 4-Cl-PBA exhibited the highest binding affinity of the PBA derivatives examined, we determined the $\mathrm{IC}_{50}$ values for inhibition by $4-\mathrm{Cl}-\mathrm{PBA}$ at three different enzyme concentrations (Figure $\mathrm{S} 13$ ) and found that they were independent of enzyme concentration (Table 1). This observation indicated that the PBA derivatives were not behaving as tight-binding inhibitors and fell into "zone $A$ " as defined by Straus and Goldstein (i.e., $K_{\mathrm{i}}^{\text {app }} /[\mathrm{E}]_{\mathrm{T}}>10$, and $\mathrm{IC}_{50} \sim K_{\mathrm{i}}^{\text {app }}$ ).(72)

To explore the role of the phenyl ring in binding, we examined the ability of MR to bind cyclohexylboronic acid and methylboronic acid (Table 1 and Figure 2). Cyclohexylboronic acid retains the hydrophobic nature of the ligand but removes the planar and aromatic character. The 867-fold loss of binding affinity for cyclohexylboronic acid (Figure S14) relative to PBA suggested that the aromaticity of the phenyl ring contributed $\sim 4.0 \mathrm{kcal} / \mathrm{mol}$ to the overall change in free energy accompanying PBA binding. Strikingly, the additional loss of van der Waals interactions resulting from replacement of the phenyl ring with a methyl group led to a massive 72000 -fold loss of binding affinity relative to PBA (Table 1). Interestingly, methylboronic acid exhibited linear mixed-type inhibition kinetics (Figure S15), likely arising from concomitant weak binding of the compound at an allosteric site $\left(\alpha K_{\mathrm{i}}=710 \mathrm{mM}\right)$.

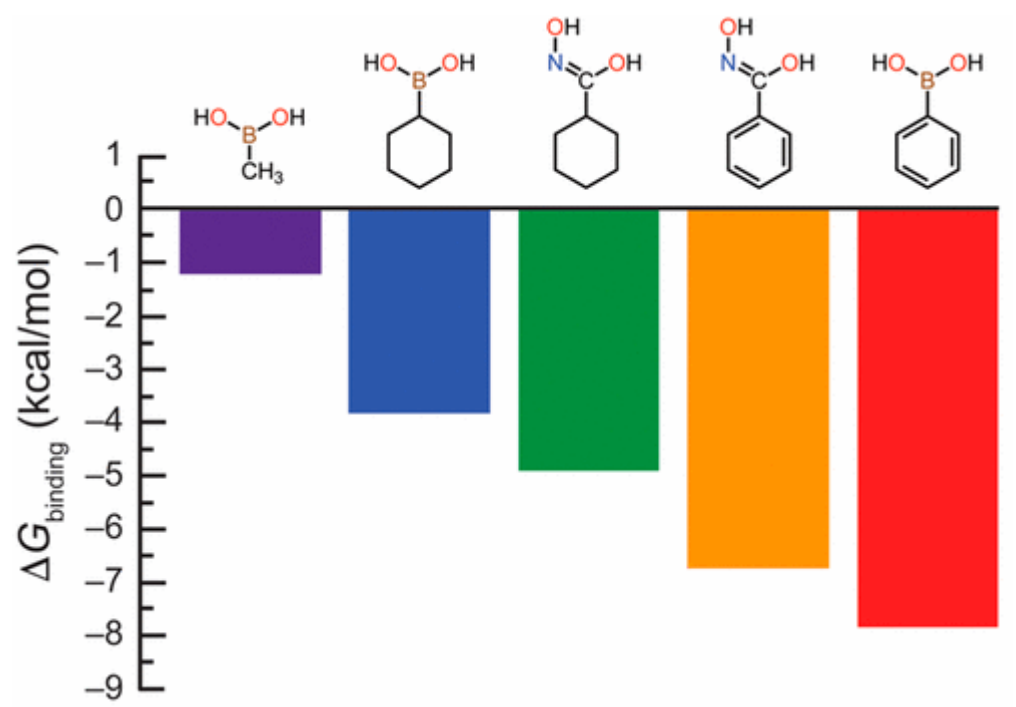

Figure 2. Comparison of the free energy changes accompanying binding ( $\Delta G_{\text {binding }}$ ) of boronic acids and hydroxamates. The $\Delta G_{\text {binding }}\left(=R T \ln K_{\mathrm{i}}\right.$ ) values of PBA (red), cyclohexylboronic acid (blue), and methylboronic acid (purple) were calculated from the $K_{\mathrm{i}}$ values listed in Table 1 . The $\Delta G_{\text {binding }}$ values for cyclohexylhydroxamate (green) and $\mathrm{BzH}$ (orange) were calculated from their $K_{\mathrm{i}}$ values of $0.25 \mathrm{mM}$ and $11.7 \mu \mathrm{M}$, respectively.(73)

MR binds PBA with an affinity that is $\sim 7$-fold greater than that exhibited for the TS analogue inhibitor benzohydroxamate $\left(\mathrm{BzH} ; K_{\mathrm{i}}=11.7 \mu \mathrm{M}\right)$. (73) Unlike PBA, replacement of the phenyl ring of BzH with a cyclohexyl ring (i.e., cyclohexylhydroxamate; $\left.K_{\mathrm{i}}=0.25 \mathrm{mM}\right)(73)$ revealed that aromaticity of the phenyl ring contributed only $\sim 1.8 \mathrm{kcal} / \mathrm{mol}$ to the overall free energy change accompanying BzH binding (Figure 2). Thus, the aromatic character of the inhibitor makes a more substantial contribution to the binding of PBA than to the binding of $\mathrm{BzH}$.

\section{${ }^{11}$ B NMR Spectroscopy}

To obtain information about the hybridization state of the boron of PBA when bound at the active site of MR in the solution state, we utilized ${ }^{11} B$ NMR spectroscopy. This approach has been employed to study the interaction 
of boronic acid-bearing inhibitors with $\beta$-lactamase,(74) $\gamma$-glutamyl transpeptidase,(75) and a variety of proteases.(18,76-83) In the absence of MR, the boron of PBA exhibited a signal with a chemical shift of 28.2 ppm in the assay buffer (Figure $3 \mathrm{~A})$, which is in accord with previous studies $(20,84)$ and arises from the neutral trigonal boronic acid species $\left[\mathrm{Ph}-\mathrm{B}(\mathrm{OH})_{2}\right]$. Upon addition of $\mathrm{MR}$, a new peak was observed at $0.97 \mathrm{ppm}$ (Figure 3B-D), which was also the sole peak present when the enzyme and PBA were at equal concentrations (Figure 3E), and suggested that there was slow exchange between the MR-bound PBA and free PBA.(79) The ${ }^{11} \mathrm{~B}$ NMR signal from PBA bound to MR was significantly sharper than that of the free inhibitor, which has also been observed for aryl boronic acid inhibitors bound to chymotrypsin. $(18,78)$ The marked upfield shift of the ${ }^{11} \mathrm{~B}$ signal of PBA in the presence of MR is consistent with additional electron density on the boron. Interestingly, the upfield chemical shift to $0.97 \mathrm{ppm}$ is greater than the chemical shift values of 2.6 and $5.7 \mathrm{ppm}$ observed for Ph$\mathrm{B}(\mathrm{OH})_{3}{ }^{-}$and for the imidazole complex with PBA, respectively.(20) Thus, the ${ }^{11} \mathrm{~B}$ NMR spectroscopic studies suggested that the boron of bound PBA likely participated in an N-B interaction (vide infra) with Lys 166 and/or His 297 and may exist either partially or fully in its anionic, $\mathrm{sp}^{3}$-hybridized state.

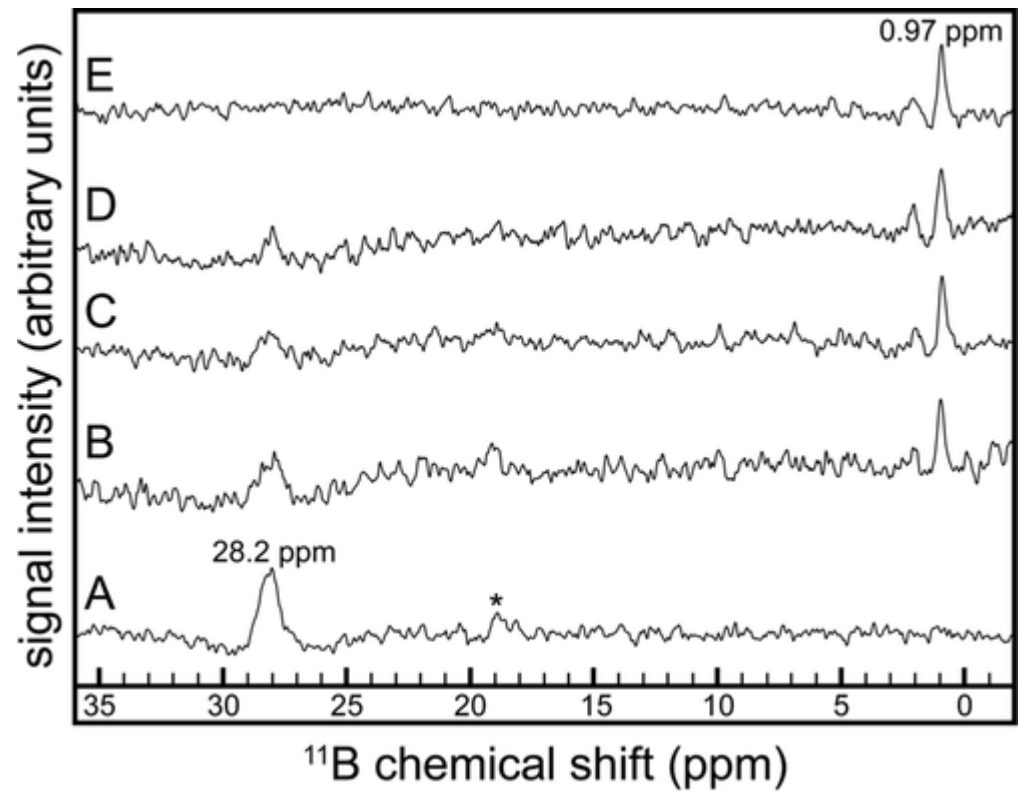

Figure 3. ${ }^{11} \mathrm{~B}$ NMR spectra of free PBA and PBA bound to wild-type MR. Shown are the observed ${ }^{11} \mathrm{~B}$ NMR spectra (32000 scans per spectrum) of PBA $(400 \mu \mathrm{M})(\mathrm{A})$ in the absence of enzyme or in the presence of (B) PBA (400 $\mu \mathrm{M})$ and $\mathrm{MR}(90 \mu \mathrm{M}),(\mathrm{C})$ PBA $(400 \mu \mathrm{M})$ and $\mathrm{MR}(130 \mu \mathrm{M}),(\mathrm{D})$ PBA $(400 \mu \mathrm{M})$ and MR $(180 \mu \mathrm{M})$, or (E) PBA (300 $\mu \mathrm{M})$ and $\mathrm{MR}(300 \mu \mathrm{M})$. The disappearance of the signal at $28.2 \mathrm{ppm}$ and the appearance of a new signal at 0.97 ppm are evident upon titration of PBA with MR. Note that the concentration of PBA was decreased to $300 \mu \mathrm{M}$ in panel $\mathrm{E}$ because concentrations of $400 \mu \mathrm{M}$ for both $\mathrm{MR}$ and PBA led to precipitation of the protein. All solutions contained $\mathrm{Na}^{+}$-HEPES buffer $(0.1 \mathrm{M}, \mathrm{pH} 7.5), \mathrm{MgCl}_{2}(3.3 \mathrm{mM})$, and $\mathrm{D}_{2} \mathrm{O}(10 \%)$. A low signal-to-noise ratio was observed in the spectra because of the requirement to use amounts of inhibitor that were approximately stoichiometric to the enzyme concentration, and higher concentrations of the enzyme $(>300 \mu \mathrm{M})$ led to protein precipitation at the concentrations of PBA employed. The weak signal at $18.9 \mathrm{ppm}\left({ }^{*}\right)$ in spectrum A likely corresponds to a minor amount of boric acid and not the $\sim 5 \%$ of PBA that exists in the anionic form at $\mathrm{pH} 7.5$ $\left[\mathrm{p} K_{\mathrm{a}}{ }^{\mathrm{B}}=8.8\right.$ (Table S2)]. $(85,86)$ The indicated ${ }^{11} \mathrm{~B}$ chemical shift values (parts per million) are relative to an external standard of $\mathrm{BF}_{3} \cdot \mathrm{OEt}_{2}$.

\section{Contribution of the Brønsted Acid-Base Catalysts to Binding of PBA}

Because the ${ }^{11} \mathrm{~B}$ NMR spectroscopic studies suggested the possibility of an N-B interaction, we examined the effect of removing the side chains of Lys 166 (K166M) and His 297 (H297N) on the binding of PBA. Neither K166M-MR nor H297N-MR is catalytically active; $(32,45)$ however, the binding affinity of these variants for PBA 
could be assessed using ITC. Although the binding event was only weakly exothermic, the thermograms for the titration of wild-type-MR, K166M-MR, and H297N-MR with PBA (Figure 4) permitted clear differentiation among the abilities of the three MR variants to bind PBA. As shown in Table 2, the $K_{d}$ value $(1.7 \mu \mathrm{M})$ for the binding of PBA to wild-type MR was in excellent agreement with the $K_{\mathrm{i}}$ value $(1.8 \mu \mathrm{M})$ determined from the inhibition experiments. Most interestingly, K166M-MR bound PBA approximately $3 \times 10^{3}$-fold less tightly than wild-type $\mathrm{MR}\left(\Delta \Delta G_{\text {binding }}=4.6 \mathrm{kcal} / \mathrm{mol}\right)$, while $\mathrm{H} 297 \mathrm{~N}-\mathrm{MR}$ bound PBA only $\sim 30$-fold less tightly than the wild-type enzyme $\left(\Delta \Delta G_{\text {binding }}=2.0 \mathrm{kcal} / \mathrm{mol}\right)$. A similar trend was reported for the binding of BzH with the wild-type, $\mathrm{K} 166 \mathrm{M}$ $\left(\Delta \Delta G_{\text {binding }}=3.5 \mathrm{kcal} / \mathrm{mol}\right)$, and $\mathrm{H} 297 \mathrm{~N}\left(\Delta \Delta G_{\text {binding }}=1.2 \mathrm{kcal} / \mathrm{mol}\right) \mathrm{MR}$ variants.(45) Thus, of the two Brønsted acid-base catalysts, Lys 166 plays a dominant role in the recognition of PBA.

Table 2. Analysis of Binding Interactions with MR Variants at $20^{\circ} \mathrm{C}$ Using ITC

\begin{tabular}{|l|l|l|l|l|}
\hline MR variant & $\boldsymbol{K}_{\mathrm{d}}(\boldsymbol{\mu M})$ & $\boldsymbol{\Delta} \boldsymbol{H}(\mathbf{k c a l} / \mathbf{m o l})$ & $\boldsymbol{\Delta} \boldsymbol{S}\left(\mathrm{cal} \mathrm{mol}^{-\mathbf{1}} \mathbf{K}^{\mathbf{- 1}}\right)$ & $\boldsymbol{\Delta} \boldsymbol{G}(\mathbf{k c a l} / \mathbf{m o l})$ \\
\hline wild-type & $1.7 \pm 0.3$ & $-0.96 \pm 0.07$ & $23.1 \pm 0.5$ & $-7.7 \pm 0.1$ \\
\hline $\mathrm{K} 166 \mathrm{Ma}$ & $4700 \pm 400$ & $-5.1 \pm 0.5$ & $-6.7 \pm 1.8$ & $-3.13 \pm 0.05$ \\
\hline $\mathrm{H} 297 \mathrm{~N}$ & $52 \pm 7$ & $-1.08 \pm 0.04$ & $15.9 \pm 0.4$ & $-5.74 \pm 0.08$ \\
\hline
\end{tabular}

aalues estimated by fixing the molar ratio $(n)$ at 1 .

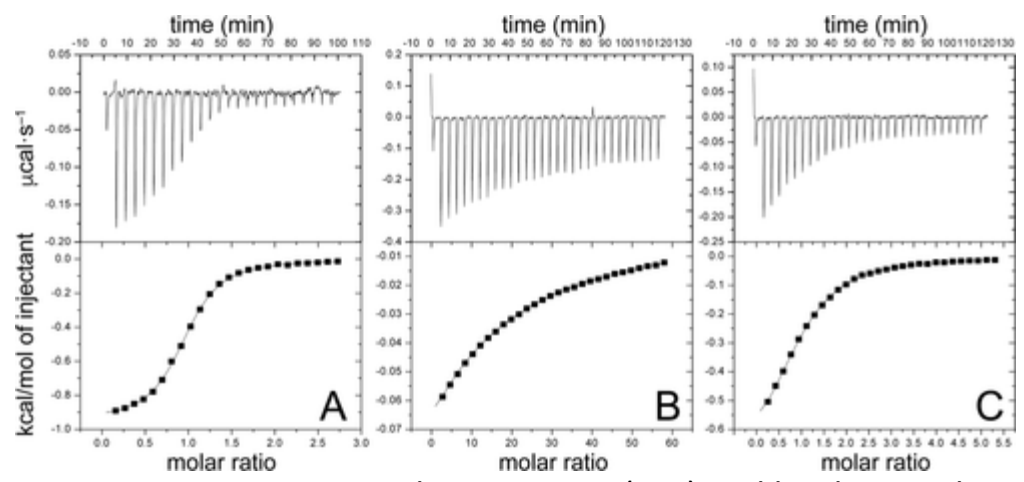

Figure 4. Representative thermograms (top) and binding isotherms (bottom) for MR variants binding PBA at 20 ${ }^{\circ} \mathrm{C}$. Titrations of (A) wild-type MR (45 $\left.\mu \mathrm{M}\right)$ with PBA (1 mM, $6 \mu \mathrm{L}$ per injection), (B) K166M-MR (60 $\left.\mu \mathrm{M}\right)$ with PBA (26.22 mM, $6 \mu \mathrm{L}$ per injection), and (C) H297N-MR ( $50 \mu \mathrm{M})$ with PBA ( $2 \mathrm{mM}, 6 \mu \mathrm{L}$ per injection). The first injection in each case (top) was $3 \mu \mathrm{L}$ and was omitted when calculating the thermodynamic parameters (see Table 2). The molar ratio is [PBA]/[MR variant].

\section{Structure of the MR.PBA Complex}

To explore the possibility of formation of an N-B interaction with the side chains of Lys 166 and/or His 297, we determined the X-ray crystal structure of the MR.PBA complex at 2.00-Å resolution. The complex crystallized as a homooctamer in space group $C 121$ due to subtle variations in the structures of the eight subunits and active sites (Table S1). The individual subunits were very similar, with root-mean-square deviations ( $r m s d s)$ for structural alignments between the $\alpha$-carbon atoms of the individual subunits ranging from 0.077 to $0.104 \AA$. In a comparison of individual structural overlays with subunit $A$, subunits $C, E$, and $G$, representing the same face of the octamer as subunit $A$, had smaller rmsds $(0.082 \pm 0.006 \AA)$, while subunits $B, D, F$, and $H$, representing the opposite face of the octamer from subunit $A$, had statistically larger rmsds $(0.102 \pm 0.001 \AA)$. The electron density for the PBA ligands was well-defined over the entire molecule, and all eight active sites of the octamer were occupied by the ligand. PBA interacted with the $\mathrm{Mg}^{2+}$ ion and formed multiple $\mathrm{H}$-bonds with the side chains of active site residues (Figure 5A,B and Figure S16). The rmsds for structural alignments of the subunit $A \alpha-$ carbon atoms of the MR.PBA complex and apo-MR (PDB entry 2MNR)(87) and MR complexes with (S)atrolactate (PDB entry 1MDR),(33) BzH (PDB entry 3UXK),(56) and Cupferron (Cfn, PDB entry 3UXL)(56) were $0.254,0.284,0.175$, and $0.198 \AA$, respectively. Hence, there was no crystallographic evidence of large structural 
changes accompanying the enzyme's binding of PBA relative to when substrate or TS analogue inhibitors are bound. Furthermore, there were no gross differences in the conformation of the 20s or 50s loops.

A

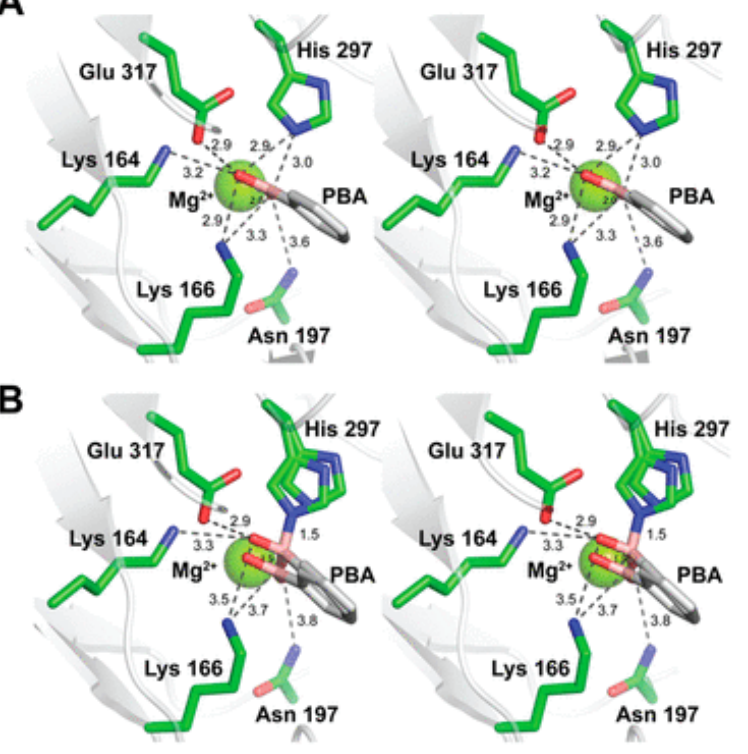

C
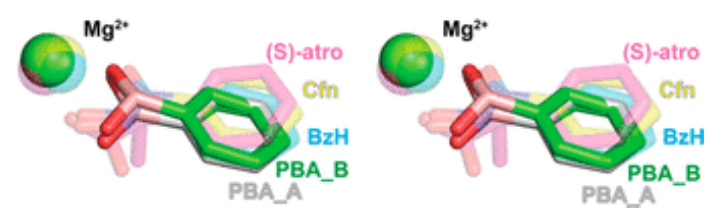

Figure 5. Active site architecture of MR with bound PBA. (A) Representative stereoview showing PBA interacting with active site residues (stick representations) and the $\mathrm{Mg}^{2+}$ ion (sphere) in chain $\mathrm{A}$ of the octamer. (B)

Representative stereoview showing PBA (two conformations, each with 50\% occupancy) interacting with active site residues (stick representations) and the $\mathrm{Mg}^{2+}$ ion (sphere) in chain $\mathrm{B}$ of the octamer. (C) Stereoview showing the bound orientations of PBA (solid stick representations) from chain A (gray) and chain B (green), the intermediate/TS analogue inhibitors BzH (PDB entry 3UXK, blue)(56) and Cfn (PDB entry 3UXL, yellow),(56) and the substrate analogue (S)-atrolactate (PDB entry $1 \mathrm{MDR}$, pink).(33) The $\mathrm{Mg}^{2+}$ ions (spheres) in the corresponding MR complexes are shown in the same color as the ligands.

As anticipated, the boron atom of PBA was located between the $\mathrm{N}^{\zeta}$ and $\mathrm{N}^{\varepsilon 2}$ atoms of the Brønsted acid-base catalysts Lys 166 and His 297, respectively (Figure 6). Initial refinements revealed that the electron density could accommodate PBA with either a trigonal geometry or a tetrahedral geometry, with only slight differences in the position of the individual atoms. Formation of an $\mathrm{N}-\mathrm{B}$ bond with the $\mathrm{N}^{\zeta}$ atom of Lys 166 was not supported by the electron density. Indeed, the $\mathrm{N}^{\zeta}$ atom of Lys 166 was directed toward the boronic acid hydroxyl group located $\sim 3.2 \AA$ from the $\mathrm{Mg}^{2+}$ ion, suggesting that Lys 166 forms an $\mathrm{H}$-bond with the hydroxyl group, rather than a dative bond with the boron atom. The average (i.e., over the octamer) Lys $166 \mathrm{~N}^{2}-\mathrm{B}$ distance was $\sim 2.9 \AA$, which is much longer than the $N-B$ distance of $1.67 \AA$ observed for covalent tetrahedral adducts with the $\varepsilon$ amino group of Lys in other structures(19) and not sufficient to form a dative bond. $(88,89)$ When PBA was modeled as a single ligand with either a trigonal planar geometry or a tetrahedral geometry, the average His 297 $\mathrm{N}^{\varepsilon 2}-\mathrm{B}$ distance was $\sim 2.5$ or $\sim 2.2 \AA$, respectively (Table S3), which also did not agree with the expected bond distances of a dative $\mathrm{N}-\mathrm{B}$ bond. Typically, $\mathrm{N}^{\varepsilon 2}-\mathrm{B}$ distances of $\sim 1.6 \AA ̊$ have been observed in covalent, tetrahedral adducts of boronic acid inhibitors with hydrolytic enzymes $(83,90,91)$ and found in calculations.(20) When we conducted DFT calculations on our system (vide infra), it was clear that the His $297 \mathrm{~N}^{\varepsilon 2}-\mathrm{B}$ distances required for formation of a tetrahedral boronic acid, as suggested from the NMR experiments, were not compatible with the 
structure when either $\mathrm{sp}^{2}$ - or $\mathrm{sp}^{3}$-hybridized PBA was modeled as a single ligand at the active sites. However, we noted that the electron density in chains $\mathrm{B}, \mathrm{D}, \mathrm{F}$, and possibly $\mathrm{H}$ could accommodate both $\mathrm{sp}^{2}$ - and $\mathrm{sp}^{3}$-hydridized PBA, as well as two conformations of the imidazole ring of His 297, at 50\% occupancy each (Figure 6). Modeling the PBA ligands and the conformations of His 297 in this manner clearly revealed the presence of a His $297 \mathrm{~N}^{\varepsilon 2}-$ $B$ dative bond with a length of $1.5 \AA$ in chains $B, D$, and F. Furthermore, the $\mathrm{C}-\mathrm{B}-\mathrm{O}^{\alpha}-\mathrm{O}^{\beta}$ dihedral angles for the modeled ligands were in reasonable agreement with those calculated using DFT calculations (Figure S17).

A

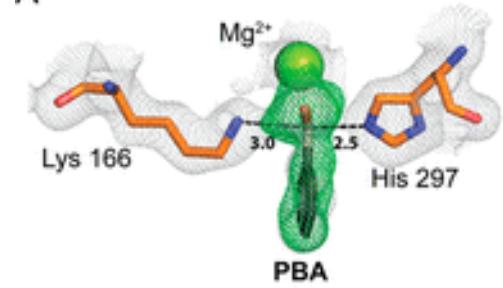

C

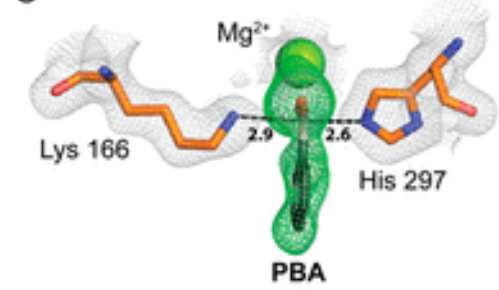

$E$

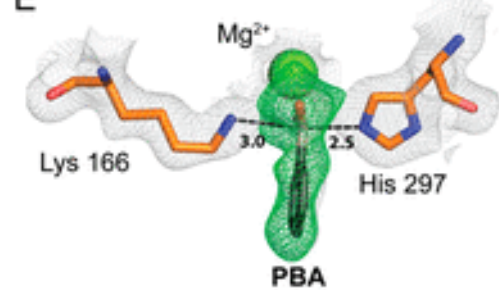

G

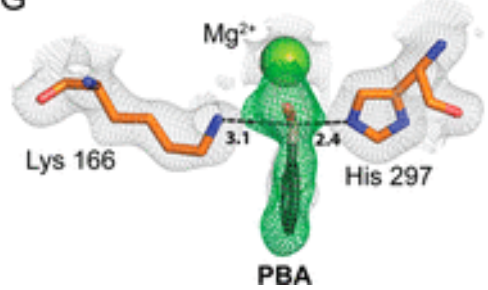

B

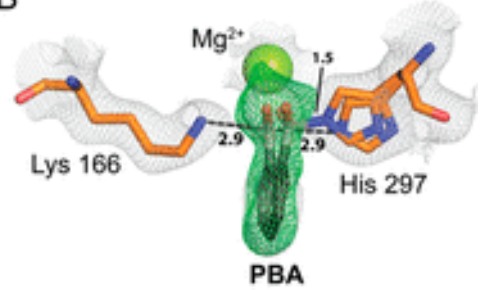

D

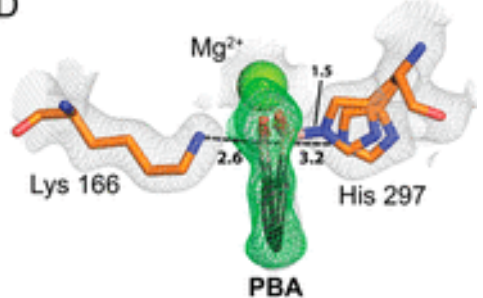

$\mathrm{F}$

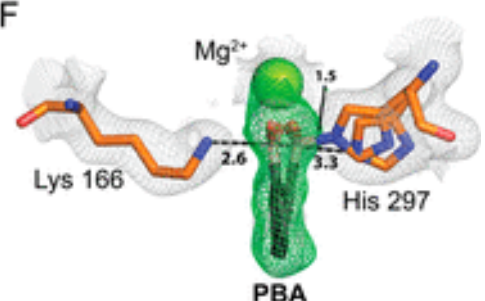

$\mathrm{H}$

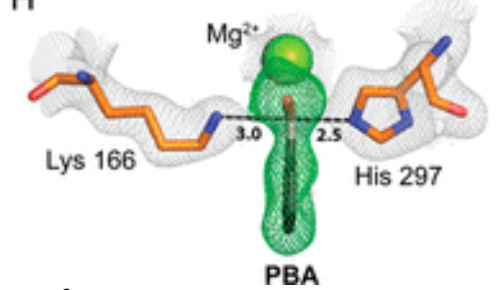

Figure 6. MR with bound PBA at 2.0- $\AA$ resolution for all eight subunits (chains A-H) of the homooctamer. The $\mathrm{Mg}^{2+}$ ion (sphere) and Brønsted acid-base catalysts Lys 166 and His 297 (stick representations) are shown. The $2 F_{\mathrm{o}}-F_{\mathrm{c}}$ map is represented by a gray mesh contoured at $1.0 \sigma$. The simulated annealing omit map $\left(F_{\mathrm{o}}-F_{\mathrm{c}}\right)$ is represented by a green mesh centered around PBA, contoured at $2.5 \sigma$. The distances are given in angstroms.

In addition to the His $297 \mathrm{~N}^{\varepsilon 2}-\mathrm{B}$ interactions, the two boronic acid hydroxyl groups can form multiple $\mathrm{H}$-bonds and/or electrostatic interactions with the nearby ( $\leq 3.6 \AA$ ) side chains of Lys 164, Lys 166, His 297, and Glu 317 (Figure 5A,B) that further contribute to the high binding affinity of PBA. Disruption of this $\mathrm{H}$-bonding network upon substitution of Lys 166 with a Met residue may account for the greater contribution to the binding free energy observed for Lys 166 , relative to His 297 , in the ITC studies.

Superposition of $(S)$-atrolactate, $\mathrm{BzH}$, and $\mathrm{Cfn}$ with PBA at the active site (Figure $5 \mathrm{C}$ ) revealed that PBA assumes a binding orientation similar to those of the intermediate/TS analogue inhibitors. In chain $A$, the boron atom was displaced by 0.8 and $0.6 \AA$ from the corresponding benzylic carbon of $\mathrm{BzH}$ and the equivalent nitrogen of $\mathrm{Cfn}$, respectively, while in chain $\mathrm{B}$, the corresponding displacements were 0.8 and $0.7 \AA$ for the $\mathrm{sp}^{2}$-hybridized PBA 
and 1.4 and $1.2 \AA$ for the $\mathrm{sp}^{3}$-hybridized PBA, respectively. Consequently, one of the hydroxyl groups of PBA was able to maintain H-bonding interactions with Glu 317 and Lys 164, similar to the interactions observed for $(S)$ atrolactate, $\mathrm{BzH}$, and $\mathrm{Cfn}$. Interestingly, this hydroxyl group appeared to occupy the sixth coordination site of the $\mathrm{Mg}^{2+}$ ion with a $\mathrm{Mg}^{2+}-\mathrm{O}$ distance of $\sim 3.2 \AA$, which resulted in a distorted octahedral coordination geometry about the divalent cation (Figure S18). The other boronic acid $\mathrm{O}$ atom was strongly coordinated to the active site $\mathrm{Mg}^{2+}$ ion with a $\mathrm{Mg}^{2+}-\mathrm{O}$ distance of $\sim 1.9 \AA$, which is reminiscent of the complex formed between PBA and the $\mathrm{Co}^{3+}$ ion at the active site of the nitrile hydratase from Pseudonocardia thermophilia.(92) Finally, comparison of the MR.PBA complex with the complexes of MR with $(S)$-atrolactate, $\mathrm{BzH}$, and $\mathrm{Cfn}$ revealed that, in all cases, the distance between the $\mathrm{N}^{\varepsilon 2}$ atom of $\mathrm{His} 297$ and the boron atom of PBA was shorter than the distances between the $\mathrm{N}^{\varepsilon 2}$ atom and the corresponding atoms of $(S)$-atrolactate, $\mathrm{BzH}$, and $\mathrm{Cfn}$, regardless of the hybridization state of the boron atom (Figure S19).

\section{DFT Calculations}

To obtain insights into the effect of varying the His $297 \mathrm{~N}^{\varepsilon 2}-\mathrm{B}$ distance on the geometry of the boronic acid group, we employed LC- $\omega$ PBE-XDM/6-31+G* calculations(62) using PBA and 4-methylimidazole. The resulting correlation (Figure S17) revealed that the average dihedral angle $\left(\mathrm{C}-\mathrm{B}-\mathrm{O}^{\alpha}-\mathrm{O}^{\beta}\right.$ ) of $\sim 165^{\circ}$ observed for $\sim \mathrm{sp}^{2}$ hydridized PBA in all chains of the X-ray crystal structure was in reasonable agreement with the average His 297 $\mathrm{N}^{\varepsilon 2}-\mathrm{B}$ distance of $2.8 \AA$, also observed in the structure (Table S3). Similarly, for the $\sim \mathrm{sp}^{3}$-hydridized PBA present (at $50 \%$ occupancy) in chains $B, D$, and $F$, the dihedral angles of $\sim 143^{\circ}$ and the $N-B$ distance of $1.5 \AA$ (Table S3) were also in reasonable agreement with the calculations (Figure S17).

Our observation of a His $297 \mathrm{~N}^{\varepsilon 2}-\mathrm{B}$ interaction in the X-ray crystal structure is in accord with the large upfield change in chemical shift of $27.2 \mathrm{ppm}$ observed in the ${ }^{11} \mathrm{~B}$ NMR experiments (Figure 3 ) and is consistent with formation of a tetrahedral boronic acid adduct. Typically, the ${ }^{11} \mathrm{~B}$ chemical shift of boronic acids changes to a higher value when the boron atom changes hybridization from $\mathrm{sp}^{2}$ to $\mathrm{sp}^{3},(93)$ and observation of such chemical shift changes in the ${ }^{11} \mathrm{~B} N \mathrm{NR}$ spectra of enzyme-boronic acid complexes has often been taken as support for the formation of $\mathrm{sp}^{3}$-hybridized boronate $\mathrm{O}-\mathrm{B}$ or $\mathrm{N}-\mathrm{B}$ adducts. $(18,74,79,81-83)$ In addition to the electron density of chains $B, D$, and $F$ supporting occupancy by an $s p^{3}$ - and an $s p^{2}$-hybridized PBA each at $50 \%$, chains $A, C, E, G$, and $\mathrm{H}$ supported the presence of an $\mathrm{sp}^{2}$-hydridzed PBA at $100 \%$ occupancy. (However, even in those subunits where only a single conformation was modeled, we cannot rule out the possibility that a range of conformations is possible within the individual active sites.) While significant steric constraints present at the enzyme active site may lead to a boron-containing inhibitor assuming an unusual binding mode wherein the boron remains $\mathrm{sp}^{2}$ hybridized as a planar ester in some hydrolytic enzymes, $(9,94)$ this does not seem to be the case for the MR-PBA interaction because the active site certainly tolerates the $\mathrm{sp}^{3}$-hybridized $\alpha$-carbon of the substrate. Although development of partial negative charge on the boron atom would mimic the negative charge on the $\alpha$-carbon of the altered substrate in the TS, the development of a full negative charge, mimicking the fully deprotonated intermediate, would likely not favor enhanced binding because it would be accompanied by a (substrate-like) tetrahedral geometry at the $\alpha$-carbon. It should also be noted that benzoic acid, with an $\mathrm{sp}^{2}$-hybridized carbon at the same position as boron in PBA, is an exceptionally weak inhibitor of MR.(70)

To further elaborate on the ability of PBA to form N-B interactions with the side chains of His 297 and Lys 166, we conducted DFT calculations using an active site model that included PBA and amino acids truncated at the $\mathrm{sp}^{3}$ or $\alpha$-carbon atoms with different combinations of protonation states (Table S4). Chain $\mathrm{F}$ was used as the model, refined with a single PBA molecule and a single conformation for the side chain of $\mathrm{His} 297$, as the initial state. Because of the apparent $\mathrm{H}$-bond between the side chain of Lys 166 and the $\mathrm{O}^{\beta}$ atom of PBA (Figure 5A,B), the $\varepsilon$-amino group of Lys 166 was assumed to be protonated. Upon relaxation, the formation of a tetrahedral adduct with the $\mathrm{N}^{\varepsilon 2}$ atom of His 297 was observed (Figure S20). The calculated value of the ${ }^{11} \mathrm{~B}$ chemical shift for the adduct was $\sim 1 \mathrm{ppm}$ (Table S4), which is in excellent agreement with the observed value of $0.97 \mathrm{ppm}$. 
Interestingly, the DFT calculations revealed that the protonation states yielding the lowest-energy configuration were Lys $164-\mathrm{NH}_{3}{ }^{+}$, Lys $166-\mathrm{NH}_{3}{ }^{+}$, and Glu $317-\mathrm{CO}_{2}{ }^{-}$. This configuration of protonation states corresponds with that expected at the intermediate, where the Glu $317-\mathrm{CO}_{2}{ }^{2-} \ldots \mathrm{HO}-\mathrm{B}$ interaction mimics the Glu $317-\mathrm{CO}_{2} \mathrm{H}^{\prime} \cdot{ }^{-} \mathrm{O}-$ enolate interaction.(95) Thus, it appears that PBA is being recognized as a TS analogue, consistent with its high binding affinity. DFT calculations also revealed that for the protonation state Lys 166- $\mathrm{NH}_{2} / \mathrm{His} 297-\mathrm{Im}$, a His 297 $\mathrm{N}^{\varepsilon 2}-\mathrm{B}$ bond formed, and only for the protonation state Lys 166- $\mathrm{NH}_{2} / \mathrm{His} 297-\mathrm{ImH}^{+}$did a Lys $166 \mathrm{~N}^{2}-\mathrm{B}$ bond form (Figure S21). The fact that the X-ray crystal structure furnishes no support for formation of such a Lys $166 \mathrm{~N}$-B bond supports the notion that the $\varepsilon$-amino group of Lys 166 is protonated in the MR.PBA complex.

\section{Conclusions}

Boronic acids have long been known as potent inhibitors of hydrolytic enzymes, forming metastable tetrahedral adducts with water or the hydroxyl groups of Ser or Thr residues that resemble the intermediate(s) and/or TS(s) formed during hydrolysis. $(5,6,9,22,23)$ To the best of our knowledge, this is the first report of a boronic acid acting as a potent inhibitor of an enzyme that catalyzes the abstraction of an $\alpha$-proton from a carbon acid substrate. MR binds PBAs with affinities that exceed those observed for the intermediate/TS analogue inhibitors $\mathrm{BzH}$ and $\mathrm{Cfn}$ by $\sim 1-2$ orders of magnitude. $(43,44)$ This unprecedented and remarkable binding affinity of PBA arises from the interaction of the boronic acid function with multiple catalytic residues at the active site (notably, Lys 164, Lys 166, His 297, and Glu 317), as well as electrostatic interactions with the $\mathrm{Mg}^{2+}$ ion and formation of a $\mathrm{N}^{\varepsilon 2}-\mathrm{B}$ interaction with His 297. The observed interactions at the active site highlight the versatility of boronic acid-heteroatom interactions in inhibitor design. Moreover, our observations suggest that boronic acids may serve as inhibitors of other enzymes that share similar active site architectures with MR (i.e., Brønsted acid-base catalysts located on either side of a carbon atom where heterolytic $\mathrm{C}-\mathrm{H}$ bond cleavage occurs), such as racemases and epimerases, many of which are therapeutic targets.(96)

\section{Supporting Information}

The Supporting Information is available free of charge at https://pubs.acs.org/doi/10.1021/acs.biochem.0c00478.

- X-ray diffraction data, kinetic and biophysical data, structural figures, and results from DFT calculations (PDF)

\section{Accession Codes}

The structure of MR with bound PBA has been deposited in the Protein Data Bank as entry 6VIM. Mandelate racemase, UniProt ID P11444.

\section{Funding}

This work was supported by Discovery Grants from the Natural Sciences and Engineering Research Council (NSERC) of Canada to S.L.B. (Grant RGPIN-2016-05083) and E.R.J. (Grant RGPIN-2016-05795).

\section{Notes}

The authors declare no competing financial interest.

\section{Acknowledgments}

The authors thank Dr. Mike Lumsden (NMR-3) for assistance with the NMR experiments and Oliver Kuehm for assistance with analysis of the ITC data. This research used resources of the Advanced Photon Source, a U.S. Department of Energy (DOE) Office of Science User Facility operated for the DOE Office of Science by Argonne 
National Laboratory under Contract DE-AC02-06CH11357. Use of LS-CAT Sector 21 was supported by the Michigan Economic Development Corp. and the Michigan Technology Tri-Corridor (Grant 085P1000817).

\section{References}

1 Trippier, P. C. and McGuigan, C. (2010) Boronic acids in medicinal chemistry: anticancer, antibacterial and antiviral applications. MedChemComm 1, 183-198, DOI: 10.1039/c0md00119h

2 Dembitsky, V. M., Al Quntar, A. A. A., and Srebnik, M. (2011) Natural and synthetic small boron-containing molecules as potential inhibitors of bacterial and fungal quorum sensing. Chem. Rev. 111, 209- 237, DOI: 10.1021/cr100093b

3 Smoum, R., Rubinstein, A., Dembitsky, V. M., and Srebnik, M. (2012) Boron containing compounds as protease inhibitors. Chem. Rev. 112, 4156- 4220, DOI: 10.1021/cr608202m

4 Ciani, L. and Ristori, S. (2012) Boron as a platform for new drug design. Expert Opin. Drug Discovery 7, 1017-1027, DOI: 10.1517/17460441.2012.717530

5 Das, B. C., Thapa, P., Karki, R., Schinke, C., Das, S., Kambhampati, S., Banerjee, S. K., Van Veldhuizen, P., Verma, A., Weiss, L. M., and Evans, T. (2013) Boron chemicals in diagnosis and therapeutics. Future Med. Chem. 5, 653-676, DOI: 10.4155/fmc.13.38

6 Whyte, G. F., Vilar, R., and Woscholski, R. (2013) Molecular recognition with boronic acids-applications in chemical biology. J. Chem. Biol. 6, 161-174, DOI: 10.1007/s12154-013-0099-0

7 Ban, H. S. and Nakamura, H. (2015) Boron-based drug design. Chem. Rec. 15, 616-635, DOI: 10.1002/tcr.201402100

8 Schrader, J., Henneberg, F., Mata, R. A., Tittmann, K., Schneider, T. R., Stark, H., Bourenkov, G., and Chari, A. (2016) The inhibition mechanism of human $20 S$ proteasomes enables next-generation inhibitor design. Science 353, 594- 598, DOI: 10.1126/science.aaf8993

9 Diaz, D. B. and Yudin, A. K. (2017) The versatility of boron in biological target engagement. Nat. Chem. 9, 731- 742, DOI: 10.1038/nchem.2814

10 Rezanka, T. and Sigler, K. (2008) Biologically active compounds of semimetals. Phytochemistry 69, 585-606, DOI: 10.1016/j.phytochem.2007.09.018

11 Frenking, G. (2015) Inorganic chemistry: peculiar boron startles again. Nature 522, 297- 298, DOI: 10.1038/522297a

12 Matthews, D. A., Alden, R. A., Birktoft, J. J., Freer, S. T., and Kraut, J. (1975) X-ray crystallographic study of boronic acid adducts with subtilisin BPN' (Novo). A model for the catalytic transition state. J. Biol. Chem. 250, 7120- 7126

13 Tulinsky, A. and Blevins, R. A. (1987) Structure of a tetrahedral transition state complex of $\alpha$-chymotrypsin dimer at 1.8-Å resolution. J. Biol. Chem. 262, 7737- 7743

14 Larsen, N. A., Turner, J. M., Stevens, J., Rosser, S. J., Basran, A., Lerner, R. A., Bruce, N. C., and Wilson, I. A. (2002) Crystal structure of a bacterial cocaine esterase. Nat. Struct. Biol. 9, 17- 21, DOI: $10.1038 / \mathrm{nsb742}$

15 Morandi, S., Morandi, F., Caselli, E., Shoichet, B. K., and Prati, F. (2008) Structure-based optimization of cephalothin-analogue boronic acids as $\beta$-lactamase inhibitors. Bioorg. Med. Chem. 16, 1195-1205, DOI: 10.1016/j.bmc.2007.10.075

16 Groll, M., Berkers, C. R., Ploegh, H. L., and Ovaa, H. (2006) Crystal structure of the boronic acid-based proteasome inhibitor bortezomib in complex with the yeast $20 \mathrm{~S}$ proteasome. Structure 14, 451-456, DOI: 10.1016/j.str.2005.11.019

17 Farr-Jones, S., Smith, S. O., Kettner, C. A., Griffin, R. G., and Bachovchin, W. W. (1989) Crystal versus solution structure of enzymes: NMR spectroscopy of a peptide boronic acid-serine protease complex in the crystalline state. Proc. Natl. Acad. Sci. U. S. A. 86, 6922-6924, DOI: 10.1073/pnas.86.18.6922

18 Tsilikounas, E., Kettner, C. A., and Bachovchin, W. W. (1993) ${ }^{11}$ B NMR spectroscopy of peptide boronic acid inhibitor complexes of $\alpha$-lytic protease. Direct evidence for tetrahedral boron in both boron-histidine and boron-serine adduct complexes. Biochemistry 32, 12651-12655, DOI: 10.1021/bi00210a013 
19 Zervosen, A., Herman, R., Kerff, F., Herman, A., Bouillez, A., Prati, F., Pratt, R. F., Frère, J. M., Joris, B., Luxen, A., Charlier, P., and Sauvage, E. (2011) Unexpected tricovalent binding mode of boronic acids within the active site of a penicillin-binding protein. J. Am. Chem. Soc. 133, 10839-10848, DOI: 10.1021/ja200696y

20 Chen, Z.-J., Tian, Z., Kallio, K., Oleson, A. L., Ji, A., Borchardt, D., Jiang, D.-E., Remington, S. J., and Ai, H.W. (2016) The N-B interaction through a water bridge: understanding the chemoselectivity of a fluorescent protein based probe for peroxynitrite. J. Am. Chem. Soc. 138, 4900- 4907, DOI: 10.1021/jacs.6b01285

21 Windsor, I. W., Palte, M. J., Lukesh, J. C., Gold, B., Forest, K. T., and Raines, R. T. (2018) Sub-picomolar inhibition of HIV-1 protease with a boronic acid. J. Am. Chem. Soc. 140, 14015-14018, DOI: 10.1021/jacs.8b07366

22 Baggio, R., Elbaum, D., Kanyo, Z. F., Carroll, P. J., Cavalli, R. C., Ash, D. E., and Christianson, D. W. (1997) Inhibition of $\mathrm{Mn}^{2+}{ }_{2}$-arginase by borate leads to the design of a transition state analogue inhibitor, 2(S)-amino-6-boronohexanoic acid. J. Am. Chem. Soc. 119, 8107-8108, DOI: 10.1021/ja971312d

23 Lanier, M., Cole, D. C., Istratiy, Y., Klein, M. G., Schwartz, P. A., Tjhen, R., Jennings, A., and Hixon, M. S. (2017) Repurposing Suzuki coupling reagents as a directed fragment library targeting serine hydrolases and related enzymes. J. Med. Chem. 60, 5209- 5215, DOI: 10.1021/acs.jmedchem.6b01224

24 Gerlt, J. A. (1998) Enzyme-catalyzed proton transfer reactions to and from carbon. In Bioorganic Chemistry: Peptides and Proteins (Hecht, S. M., Ed.) pp 279-311, Oxford University Press, New York.

25 Kluger, R. (1990) lonic intermediates in enzyme-catalyzed carbon-carbon bond formation: patterns, prototypes, probes, and proposals. Chem. Rev. 90, 1151-1169, DOI: 10.1021/cr00105a005

26 Richard, J. P. and Amyes, T. L. (2001) Proton transfer at carbon. Curr. Opin. Chem. Biol. 5, 626- 633, DOI: 10.1016/S1367-5931(01)00258-7

27 Rose, I. A. (1966) Mechanisms of enzyme action. Annu. Rev. Biochem. 35, 23-56, DOI: 10.1146/annurev.bi.35.070166.000323

28 Kenyon, G. L. and Hegeman, G. D. (2006) Mandelate racemase. Adv. Enzymol. Relat. Areas. Mol. Biol. 50, 325- 360, DOI: 10.1002/9780470122952.ch7

29 Gerlt, J. A., Kenyon, G. L., Kozarich, J. W., Neidhart, D. C., Petsko, G. A., and Powers, V. M. (1992) Mandelate racemase and class-related enzymes. Curr. Opin. Struct. Biol. 2, 736-742, DOI: 10.1016/0959440X(92)90209-P

30 Kenyon, G. L., Gerlt, J. A., Petsko, G. A., and Kozarich, J. W. (1995) Mandelate racemase: structure-function studies of a pseudosymmetric enzyme. Acc. Chem. Res. 28, 178- 186, DOI: 10.1021/ar00052a003

31 Bearne, S. L. and St. Maurice, M. (2017) A paradigm for $\mathrm{CH}$ bond cleavage: structural and functional aspects of transition state stabilization by mandelate racemase. Adv. Protein Chem. Struct. Biol. 109, 113- 160, DOI: 10.1016/bs.apcsb.2017.04.007

32 Landro, J. A., Kallarakal, A. T., Ransom, S. C., Gerlt, J. A., Kozarich, J. W., Neidhart, D. J., and Kenyon, G. L. (1991) Mechanism of the reaction catalyzed by mandelate racemase. 3. Asymmetry in reactions catalyzed by the H297N mutant. Biochemistry 30, 9274-9281, DOI: 10.1021/bi00102a020

33 Landro, J. A., Gerlt, J. A., Kozarich, J. W., Koo, C. W., Shah, V. J., Kenyon, G. L., Neidhart, D. J., Fujita, S., and Petsko, G. A. (1994) The role of lysine 166 in the mechanism of mandelate racemase from Pseudomonas putida: mechanistic and crystallographic evidence for stereospecific alkylation by (R)- $\alpha$-phenylglycidate. Biochemistry 33, 635-643, DOI: 10.1021/bi00169a003

34 Kallarakal, A. T., Mitra, B., Kozarich, J. W., Gerlt, J. A., Clifton, J. G., Petsko, G. A., and Kenyon, G. L. (1995) Mechanism of the reaction catalyzed by mandelate racemase: structure and mechanistic properties of the K166R mutant. Biochemistry 34, 2788- 2797, DOI: 10.1021/bi00009a007

35 Arnal-Hérault, C., Pasc, A., Michau, M., Cot, D., Petit, E., and Barboiu, M. (2007) Functional G-quartet macroscopic membrane films. Angew. Chem. 119, 8561-8565, DOI: 10.1002/ange.200702605 
36 Galbraith, E., Kelly, A. M., Fossey, J. S., Kociok-Köhn, G., Davidson, M. G., Bull, S. D., and James, T. D. (2009) Dynamic covalent self-assembled macrocycles prepared from 2-formyl-aryl-boronic acids and 1,2-amino alcohols. New J. Chem. 33, 181-185, DOI: 10.1039/B815138E

37 Hutin, M., Bernardinelli, G., and Nitschke, J. R. (2008) An iminoboronate construction set for subcomponent self-assembly. Chem. Eur. J. 14, 4585-4593, DOI: 10.1002/chem.200800074

38 Larkin, J. D., Fossey, J. S., James, T. D., Brooks, B. R., and Bock, C. W. (2010) A computational investigation of the nitrogen-boron interaction in o-(N,N-dialkylaminomethyl)arylboronate systems. J. Phys. Chem. A 114, 12531-12539, DOI: 10.1021/jp1087674

39 Zhu, L., Shabbir, S. H., Gray, M., Lynch, V. M., Sorey, S., and Anslyn, E. V. (2006) A structural investigation of the $\mathrm{N}-\mathrm{B}$ interaction in an $\mathrm{o}-(\mathrm{N}, \mathrm{N}$-dialkylaminomethyl)arylboronate system. J. Am. Chem.

Soc. 128, 1222-1232, DOI: 10.1021/ja055817c

40 Franzen, S., Ni, W., and Wang, B. (2003) Study of the mechanism of electron-transfer quenching by boronnitrogen adducts in fluorescent sensors. J. Phys. Chem. B 107, 12942-12948, DOI: 10.1021/jp027457a

41 Cai, G., Deng, L., Fryszczyn, B. G., Brown, N. G., Liu, Z., Jiang, H., Palzkill, T., and Song, Y. (2012) Thermodynamic investigation of inhibitor binding to 1-deoxy-d-xylulose-5-phosphate reductoisomerase. ACS Med. Chem. Lett. 3, 496-500, DOI: 10.1021/ml300071w

42 Cal, P. M., Frade, R. F., Cordeiro, C., and Gois, P. M. (2015) Reversible lysine modification on proteins by using functionalized boronic acids. Chem. Eur. J. 21, 8182-8187, DOI: 10.1002/chem.201500127

43 St. Maurice, M. and Bearne, S. L. (2000) Reaction intermediate analogues for mandelate racemase: interaction between Asn 197 and the $\alpha$-hydroxyl of the substrate promotes catalysis. Biochemistry 39, 13324-13335, DOI: 10.1021/bi001144t

44 Bourque, J. R., Burley, R. K., and Bearne, S. L. (2007) Intermediate analogue inhibitors of mandelate racemase: $\mathrm{N}$-Hydroxyformanilide and Cupferron. Bioorg. Med. Chem. Lett. 17, 105-108, DOI: 10.1016/j.bmcl.2006.09.079

45 Nagar, M. and Bearne, S. L. (2015) An additional role for the Brønsted acid-base catalysts of mandelate racemase in transition state stabilization. Biochemistry 54,6743-6752, DOI: 10.1021/acs.biochem.5b00982

46 Narmandakh, A. and Bearne, S. L. (2010) Purification of recombinant mandelate racemase: improved catalytic activity. Protein Expression Purif. 69, 39- 46, DOI: 10.1016/j.pep.2009.06.022

47 Sambrook, J., Fritsch, E. F., and Maniatis, T. (1989) Molecular Cloning. A Laboratory Manual, Cold Spring Harbor Laboratory Press, Plainview, NY.

48 Gasteiger, E., Gattiker, A., Hoogland, C., Ivanyi, I., Appel, R. D., and Bairoch, A. (2003) ExPASy: The proteomics server for in-depth protein knowledge and analysis. Nucleic Acids Res. 31, 3784- 3788, DOI: 10.1093/nar/gkg563

49 Sharp, T. R., Hegeman, G. D., and Kenyon, G. L. (1979) A direct kinetic assay for mandelate racemase using circular dichroic measurements. Anal. Biochem. 94, 329-334, DOI: 10.1016/0003-2697(79)90368-3

50 Segel, I. H. (1975) Enzyme Kinetics, John Wiley and Sons, Inc., New York.

51 Cobas, J. C., Bernstein, M. A., Martín-Pastor, M., and Tahoces, P. G. (2006) A new general-purpose fully automatic baseline-correction procedure for 1D and 2D NMR data. J. Magn. Reson. 183, 145- 151, DOI: 10.1016/j.jmr.2006.07.013

52 Vonrhein, C., Flensburg, C., Keller, P., Sharff, A., Smart, O., Paciorek, W., Womack, T., and Bricogne, G. (2011) Data processing and analysis with the autoPROC toolbox. Acta Crystallogr., Sect. D: Biol. Crystallogr. 67, 293-302, DOI: 10.1107/S0907444911007773

53 Evans, P. R. and Murshudov, G. N. (2013) How good are my data and what is the resolution?. Acta Crystallogr., Sect. D: Biol. Crystallogr. 69, 1204-1214, DOI: $10.1107 /$ S0907444913000061

54 French, G. S. and Wilson, K. S. (1978) On the treatment of negative intensity observations. Acta Crystallogr., Sect. A: Cryst. Phys., Diffr., Theor. Gen. Crystallogr. A34, 517- 525, DOI: 10.1107/S0567739478001114

55 Winn, M. D., Ballard, C. C., Cowtan, K. D., Dodson, E. J., Emsley, P., Evans, P. R., Keegan, R. M., Krissinel, E. B., Leslie, A. G., McCoy, A., McNicholas, S. J., Murshudov, G. N., Pannu, N. S., Potterton, E. A., Powell, H. R., Read, R. J., Vagin, A., and Wilson, K. S. (2011) Overview of the CCP4 suite and current 
developments. Acta Crystallogr., Sect. D: Biol. Crystallogr. 67, 235-242, DOI: 10.1107/S0907444910045749

56 Lietzan, A. D., Nagar, M., Pellmann, E. A., Bourque, J. R., Bearne, S. L., and St. Maurice, M. (2012) Structure of mandelate racemase with bound intermediate analogues benzohydroxamate and Cupferron. Biochemistry 51, 1160-1170, DOI: 10.1021/bi2018514

57 McCoy, A. J., Grosse-Kunstleve, R. W., Adams, P. D., Winn, M. D., Storoni, L. C., and Read, R. J. (2007) Phaser crystallographic software. J. Appl. Crystallogr. 40,658-674, DOI: 10.1107/S0021889807021206

58 Emsley, P., Lohkamp, B., Scott, W. G., and Cowtan, K. (2010) Features and development of Coot. Acta Crystallogr., Sect. D: Biol. Crystallogr. 66, 486- 501, DOI: 10.1107/S0907444910007493

59 Afonine, P. V., Grosse-Kunstleve, R. W., Echols, N., Headd, J. J., Moriarty, N. W., Mustyakimov, M., Terwilliger, T. C., Urzhumtsev, A., Zwart, P. H., and Adams, P. D. (2012) Towards automated crystallographic structure refinement with phenix.refine. Acta Crystallogr., Sect. D: Biol. Crystallogr. 68, 352- 367, DOI: $10.1107 /$ S0907444912001308

60 Moriarty, N. W., Grosse-Kunstleve, R. W., and Adams, P. D. (2009) Electronic Ligand Builder and Optimization Workbench (eLBOW): a tool for ligand coordinate and restraint generation. Acta Crystallogr., Sect. D: Biol. Crystallogr. 65, 1074- 1080, DOI: 10.1107/S0907444909029436

61 Frisch, M. J., Trucks, G. W., Schlegel, H. B., Scuseria, G. E., Robb, M. A., Cheeseman, J. R., Scalmani, G., Barone, V., Mennucci, B., Petersson, G. A., Nakatsuji, H., Caricato, M., Li, X., Hratchian, H. P., Izmaylov, A. F., Bloino, G., Zheng, Q., Sonnenberg, J. L., Hada, M., Ehara, M., Toyota, K., Fukuda, R., Hasegawa, J., Ishida, M., Nakajima, T., Honda, Y., Kitao, O., Nakai, H., Vreven, T., Montgomery, J. A., Jr., Peralta, J. E., Ogliaro, F., Bearpark, M., Heyd, J. J., Brothers, E., Kudin, K. N., Staroverov, V. N., Kobayashi, R., Normand, J., Raghavachari, K., Rendell, A., Burant, J. C., Iyengar, S. S., Tomasi, J., Cossi, M., Rega, N., Millam, J. M., Klene, M., Knox, J. E., Cross, J. B., Bakken, V., Adamo, C., Jaramillo, J., Gomperts, R., Stratmann, E. E., Yazyev, O., Austin, A. J., Cammi, R., Pomelli, C., Ochterski, J. W., Martin, R. L., Morokuma, K., Zakrzewski, V. G., Voth, G. A., Salvador, P., Dannenberg, J. J., Dapprich, S., Daniels, A. D., Farkas, O., Foresman, J. B., Ortiz, J. V., Cioslowski, J., and Fox, D. J. (2009) Gaussian 09, rev. B.1, Gaussian Inc., Wallingford, CT.

62 Otero-de-la-Roza, A. and Johnson, E. R. (2013) Non-covalent interactions and thermochemistry using XDMcorrected hybrid and range-separated hybrid density functionals. J. Chem. Phys. 138, 204109, DOI: $10.1063 / 1.4807330$

63 Vydrov, O. A. and Scuseria, G. E. (2006) Assessment of a long-range corrected hybrid functional. J. Chem. Phys. 125, 234109, DOI: 10.1063/1.2409292

64 Johnson, E. R. (2017) The Exchange-Hole Dipole Moment Dispersion Model. In Non-covalent Interactions in Quantum Chemistry and Physics (Otero-de-la-Roza, A., and DiLabio, G. A., Eds.) pp 169- 194, Elsevier.

65 Schafer, S. L., Barrett, W. C., Kallarakal, A. T., Mitra, B., Kozarich, J. W., Gerlt, J. A., Clifton, J. G., Petsko, G. A., and Kenyon, G. L. (1996) Mechanism of the reaction catalyzed by mandelate racemase: structure and mechanistic properties of the D270N mutant. Biochemistry 35, 5662-5669, DOI: 10.1021/bi960174m

66 Cheeseman, J. R., Trucks, G. W., Keith, T. A., and Frisch, M. J. (1996) A comparison of models for calculating nuclear magnetic resonance shielding tensors. J. Chem. Phys. 104, 5497- 5509, DOI: 10.1063/1.471789

67 St. Maurice, M. and Bearne, S. L. (2002) Kinetics and thermodynamics of mandelate racemase catalysis. Biochemistry 41, 4048- 4058, DOI: 10.1021/bi016044h

68 Koster, J. F. and Veeger, C. (1968) The relationship between temperature-inducible allosteric effects and the activation energies of amino-acid oxidases. Biochim. Biophys. Acta 167, 48-63, DOI: 10.1016/00052744(68)90276-3

69 Philipp, M. and Bender, M. L. (1971) Inhibition of serine proteases by arylboronic acids. Proc. Natl. Acad. Sci. U. S. A. $68,478-480$, DOI: $10.1073 /$ pnas.68.2.478

70 Hegeman, G. D., Rosenberg, E. Y., and Kenyon, G. L. (1970) Mandelic acid racemase from Pseudomonas putida. Purification and properties of the enzyme. Biochemistry 9, 4029-4036, DOI: 10.1021/bi00823a001 
71 Fetter, C. M., Morrison, Z. A., Nagar, M., Douglas, C. D., and Bearne, S. L. (2019) Altering the Y137-K164-K166 triad of mandelate racemase and its effect on the observed $\mathrm{pKa}$ of the Brønsted base catalysts. Arch. Biochem. Biophys. 666, 116-126, DOI: 10.1016/j.abb.2019.03.011

72 Straus, O. H. and Goldstein, S. (1943) Zone behaviour of enzymes. J. Gen. Physiol. 26, 559- 585, DOI: 10.1085/jgp.26.6.559

73 St. Maurice, M. and Bearne, S. L. (2004) Hydrophobic nature of the active site of mandelate racemase. Biochemistry 43, 2524-2532, DOI: 10.1021/bi036207x

74 Baldwin, J. E., Claridge, T. D. W., Derome, A. E., Smith, B. D., Twyman, M., and Waley, S. G. (1991) Direct observation of a tetrahedral boronic acid- $\beta$-lactamase complex using ${ }^{11} \mathrm{~B}$ NMR spectroscopy. J. Chem. Soc., Chem. Commun. 573- 574, DOI: 10.1039/C39910000573

75 London, R. E. and Gabel, S. A. (2001) Development and evaluation of a boronate inhibitor of $y$-glutamyl transpeptidase. Arch. Biochem. Biophys. 385, 250- 258, DOI: 10.1006/abbi.2000.2169

76 Adebodun, F. and Jordan, F. (1988) ${ }^{11} \mathrm{~B}$ nuclear magnetic resonance studies of the structure of the transitionstate analog phenylboronic acid bound to chymotrypsin. J. Am. Chem. Soc. 110, 309-310, DOI: 10.1021/ja00209a060

77 Adebodun, F. and Jordan, F. (1989) Multinuclear magnetic resonance studies on serine protease transition state analogues. J. Cell. Biochem. 40, 249-260, DOI: 10.1002/jcb.240400213

78 Baldwin, J. E., Claridge, T. D. W., Derome, A. E., Schofield, C. J., and Smith, B. D. (1991) ${ }^{11}$ B NMR studies of an aryl boronic acid bound to chymotrypsin and subtilisin. Bioorg. Med. Chem. Lett. 1, 9-12, DOI: 10.1016/S0960-894X(01)81080-5

79 Zhong, S., Jordan, F., Kettner, C., and Polgar, L. (1991) Observation of tightly bound ${ }^{11} B$ nuclear magnetic resonance signals on serine proteases. Direct solution evidence for tetrahedral geometry around the boron in the putative transition-state analogs. J. Am. Chem. Soc. 113, 9429-9435, DOI: 10.1021/ja00025a001

80 Sudmeier, J. L., Günther, U. L., Gutheil, W. G., Coutts, S. J., Snow, R. J., Barton, R. W., and Bachovchin, W. W. (1994) Solution structures of active and inactive forms of the DP IV (CD26) inhibitor Pro-boroPro determined by NMR spectroscopy. Biochemistry 33, 12427-12438, DOI: 10.1021/bi00207a009

81 Deadman, J. J., Elgendy, S., Goodwin, C. A., Green, D., Baban, J. A., Patel, G., Skordalakes, E., Chino, N., Claeson, G., Kakkar, V. V., and Scully, M. F. (1995) Characterization of a class of peptide boronates with neutral P1 side chains as highly selective inhibitors of thrombin. J. Med.

Chem. 38, 1511- 1522, DOI: 10.1021/jm00009a012

82 London, R. E. and Gabel, S. A. (2002) Formation of a trypsin-borate-4-aminobutanol ternary complex. Biochemistry 41, 5963- 5967, DOI: 10.1021/bi025583z

83 Transue, T. R., Gabel, S. A., and London, R. E. (2006) NMR and crystallographic characterization of adventitious borate binding by trypsin. Bioconjugate Chem. 17, 300- 308, DOI: 10.1021/bc0502210

84 Stolowitz, M. L., Ahlem, C., Hughes, K. A., Kaiser, R. J., Kesicki, E. A., Li, G., Lund, K. P., Torkelson, S. M., and Wiley, J. P. (2001) Phenylboronic acid-salicylhydroxamic acid bioconjugates. 1. A novel boronic acid complex for protein immobilization. Bioconjugate Chem. 12, 229- 239, DOI: 10.1021/bc0000942

85 Good, C. D. and Ritter, D. M. (1962) Alkenylboranes. II. Improved preparative methods and new observations on methylvinylboranes. J. Am. Chem. Soc. 84, 1162-1166, DOI: 10.1021/ja00866a021

86 Dewar, M. J. S. and Jones, R. (1967) New heteroaromatic compounds. XXV. Studies of salt formation in boron oxyacids by ${ }^{11} \mathrm{~B}$ nuclear magnetic resonance. J. Am. Chem. Soc. 89, 2408-2410, DOI: 10.1021/ja00986a029

87 Neidhart, D. J., Howell, P. L., Petsko, G. A., Powers, V. M., Li, R. S., Kenyon, G. L., and Gerlt, J. A. (1991) Mechanism of the reaction catalyzed by mandelate racemase. 2. Crystal structure of mandelate racemase at $2.5-\AA \AA$ resolution: identification of the active site and possible catalytic residues. Biochemistry 30, 9264-9273, DOI: 10.1021/bi00102a019

88 Takahashi, L. H., Radhakrishnan, R., Rosenfield, R. E., and Meyer, E. F. (1989) Crystallographic analysis of the inhibition of porcine pancreatic elastase by a peptidyl boronic acid: structure of a reaction intermediate. Biochemistry 28, 7610-7617, DOI: 10.1021/bi00445a016 
89 Smith, T. P., Windsor, I. W., Forest, K. T., and Raines, R. T. (2017) Stilbene boronic acids form a covalent bond with human transthyretin and inhibit its aggregation. J. Med. Chem. 60, 7820-7834, DOI: 10.1021/acs.jmedchem.7b00952

90 Stoll, V. S., Eger, B. T., Hynes, R. C., Martichonok, V., Jones, J. B., and Pai, E. F. (1998) Differences in binding modes of enantiomers of 1-acetamido boronic acid based protease inhibitors: crystal structures of $\gamma^{-}$ chymotrypsin and subtilisin Carlsberg complexes. Biochemistry 37, 451-462, DOI: 10.1021/bi971166o

91 Alterio, V., Cadoni, R., Esposito, D., Vullo, D., Fiore, A. D., Monti, S. M., Caporale, A., Ruvo, M., Sechi, M., Dumy, P., Supuran, C. T., De Simone, G., and Winum, J. Y. (2016) Benzoxaborole as a new chemotype for carbonic anhydrase inhibition. Chem. Commun. 52, 11983-11986, DOI: 10.1039/C6CC06399C

92 Martinez, S., Wu, R., Sanishvili, R., Liu, D., and Holz, R. (2014) The active site sulfenic acid ligand in nitrile hydratases can function as a nucleophile. J. Am. Chem. Soc. 136, 1186-1189, DOI: 10.1021/ja410462j

93 Kidd, R. G. (1983) Boron-11. In NMR of Newly Accessible Nuclei (Laszlo, P., Ed.) pp 49- 77, Academic Press, New York.

94 Bone, R., Frank, D., Kettner, C. A., and Agard, D. A. (1989) Structural analysis of specificity: $\alpha$-lytic protease complexes with analogues of reaction intermediates. Biochemistry 28, 7600-7609, DOI: 10.1021/bi00445a015

95 Mitra, B., Kallarakal, A. T., Kozarich, J. W., Gerlt, J. A., Clifton, J. G., Petsko, G. A., and Kenyon, G. L. (1995) Mechanism of the reaction catalyzed by mandelate racemase: importance of electrophilic catalysis by glutamic acid 317. Biochemistry 34, 2777- 2787, DOI: 10.1021/bi00009a006

96 Conti, P., Tamborini, L., Pinto, A., Blondel, A., Minoprio, P., Mozzarelli, A., and De Micheli, C. (2011) Drug discovery targetting amino acid racemases. Chem. Rev. 111, 6919-6946, DOI: 10.1021/cr2000702 